NBER WORKING PAPER SERIES

\title{
THE EFFECTS OF 401(k) PLANS ON HOUSEHOLD WEALTH: DIFFERENCES ACROSS EARNINGS GROUPS
}

\author{
Eric M. Engen \\ William G. Gale \\ Working Paper 8032 \\ http://www.nber.org/papers/w8032 \\ NATIONAL BUREAU OF ECONOMIC RESEARCH \\ 1050 Massachusetts Avenue \\ Cambridge, MA 02138 \\ December 2000
}

This paper was presented at the TAPES conference in May, 2000. For helpful comments, we thank Joseph Altonji, Dan Benjamin, Doug Bernheim, Darrel Cohen, Bill Dickens, Glenn Hubbard, Arthur Kennickell, Michael Littlewood, Bruce Meyer, Derek Neal, Karen Pence, Maria Perozek, Andrew Samwick, John Karl Scholz, Jonathan Skinner, Chris Taber, and seminar participants at Brookings, Northwestern, TAPES, and Tax Economists' Forum. We also thank Tats Kanenari and Norma Coe for outstanding research assistance, Bill Even for providing the CPS data extract used in the paper, and Stacy Furukawa for assistance with the data. Gale gratefully acknowledges financial support from the National Institute on Aging under grant AG11836. All opinions are our own and should not be attributed to the staff, officers, or trustees of the Federal Reserve Board, the Brookings Institution, or the NBER.

(C) 2000 by Eric M. Engen and William G. Gale. All rights reserved. Short sections of text, not to exceed two paragraphs, may be quoted without explicit permission provided that full credit, including $\mathbb{C}$ notice, is given to the source. 
The Effects of 401(k) Plans on Household Wealth:

Differences Across Earnings Groups

Eric M. Engen and William G. Gale

NBER Working Paper No. 8032

December 2000

\begin{abstract}
$\underline{\text { ABSTRACT }}$
This paper provides a new econometric specification and new evidence on the impact of 401(k) plans on household wealth. We allow the impact of $401(\mathrm{k}) \mathrm{s}$ to vary over both time and earnings groups. Our specification--motivated by a variety of theoretical considerations and data patterns--generalizes earlier work in the literature, and we show that the modeling constraints imposed by previous authors are rejected by the data. Using data from 1987 and 1991 from the Survey of Income and Program Participation, we find that the effects of $401(\mathrm{k}) \mathrm{s}$ on household wealth vary significantly by earnings level. Our analysis implies that 401(k)s held by groups with low earnings, who hold a small portion of 401(k) balances, are more likely to represent additions to net wealth than 401(k)s held by high-earning groups, who hold the bulk of $401(\mathrm{k})$ assets. Overall, between 0 and 30 percent of $401(\mathrm{k})$ balances represent net additions to private saving in the sample period.
\end{abstract}

Eric M. Engen

Federal Reserve Board

Mail Stop 93

Washington, DC 20551

(202) 452-2980

Eengen@frb.gov
William G. Gale

The Brookings Institution

1775 Massachusetts Avenue, NW

Washington, DC 20036

(202) 797-6148

Wgale@brookings.edu 
This paper provides a new analysis of a question of increasing importance and significant controversy: the impact of 401(k) plans on households' wealth. Deferred compensation, or 401(k), plans are employment-based saving incentives featuring tax-deductible contributions by the employer and employee, tax-free accrual of earnings, and annual contribution limits. Withdrawals are taxed as ordinary income and may also be subject to penalties, depending on the age of the account holder. Originally authorized in 1978, 401(k) plans began to grow rapidly after regulations were issued in the early 1980s. In 1984, active 401(k) participants numbered 7.5 million and aggregate contributions totaled $\$ 16$ billion. By 1996, active participants numbered almost 31 million, contributions were $\$ 104$ billion and balances exceeded $\$ 1,061$ billion (Department of Labor 2000). In short, 401(k) plans have become a major tax -preferred saving vehicle over the last 15 to 20 years.

Over the same period, a growing literature on how 401(k) plans affect household saving has emerged. The central issue addressed is simple: what proportion of 401(k) contributions or balances represent net additions to national (private plus public) saving? Contributions raise private saving when households finance the contributions with reductions in consumption or increases in labor supply. Private saving also rises even if the contributions are financed by the associated tax cut; this emphasizes the importance of considering the impact on both public and private saving. However, 401(k) plans do not raise private saving when households finance contributions with reductions in existing assets, with saving that would have been undertaken even in the absence of the plan, or with increases in debt. Moreover, the tax breaks associated with $401(\mathrm{k}) \mathrm{s}$ tend to reduce public saving.

Although the central issue is straightforward, developing reliable and robust answers has proven difficult for several reasons. First, saving behavior differs significantly across households. Evidence indicates that households that participate in, or are eligible for, 401(k)s have systematically stronger tastes for saving than other households. Second, the average taste for saving among eligible or ineligible households may have shifted systematically over time. Finally, since the early 1980s, financial markets and underlying 
economic factors have changed dramatically. The attempt to control for these three complicating factors has been a major theme of previous work. Despite these efforts, previous research has reached a wide variety of conclusions regarding 401(k)s and saving. Poterba, Venti, and Wise (1996a, page 92) conclude that “...401(k) contributions represent new saving, rather than simply being a substitute for other financial asset saving.” However, Engen, Gale and Scholz (1996, page 115) conclude that “...little, if any, of the overall contributions to existing saving incentives have raised saving."

This paper points the way toward a reconciliation of these findings. Our key modeling innovation is to allow the impact of $401(\mathrm{k}) \mathrm{s}$ to vary simultaneously over both time and earnings groups. Previous work has considered each item separately. Our specification generalizes models used in earlier research. We show that the modeling constraints imposed in previous studies are soundly rejected by the data. Using data from 1987 and 1991, we find that the effects of $401(\mathrm{k}) \mathrm{s}$ on wealth vary significantly by earnings level. Our analysis implies that $401(\mathrm{k}) \mathrm{s}$ held by groups with low earnings, who hold a small portion of overall $401(\mathrm{k})$ assets, are more likely to represent net wealth than 401(k)s held by high-earnings groups, who hold the bulk of 401(k) balances. We also find that 401(k)s held by homeowners or IRA holders, both of whom save substantial amounts in other forms and who hold the bulk of $401(\mathrm{k})$ assets, are less likely to be new saving than are 401(k) balances held by renters or non-IRA holders. Thus, between 0 and 30 percent of $401(\mathrm{k})$ balances in the sample period represent net additions to private saving.

In section I, we describe the data set used in this and previous work, and highlight several key

empirical patterns. Section II describes and critiques previous research. Section III develops our modeling strategy. Section IV presents the main results. Sections V and VI examine a variety of extensions of the basic results. Section VII provides concluding remarks and places the results in a broader context.

\section{Data}

Following previous research on 401(k)s, we use data from 1984, 1987, and 1991, available in the 
Survey of Income and Program Participation (SIPP), which is conducted by the Bureau of the Census. ${ }^{1}$ Our sample includes only families where the reference person is 25-64 years old, at least one person is employed, and no individual is self-employed. ${ }^{2}$ We use this group for several reasons. $401(\mathrm{k})$ plans are employmentbased and are typically unavailable to the self-employed. For people aged 65 and older, retirement issues may complicate the analysis. SIPP questions about 401(k) plans are asked only of people aged 25 and older. Also, we exclude households with inconsistent asset data. ${ }^{3}$ These criteria leave samples of 9,310 households in $1984,10,669$ in 1987 and 10,266 in $1991 .^{4}$

The SIPP is the only nationally representative survey with data on 401(k) eligibility and wealth during the 1980s, when 401(k)s grew rapidly. But the SIPP has several shortcomings worth noting. First, there is no information on $401(\mathrm{k})$ balances for 1984. Second, mortgage debt and house value are top coded. Based on sensitivity analyses we have conducted, we believe that top coding does not have an important influence on our results. ${ }^{5}$ Third, Curtin, Juster, and Morgan (1989) compare the SIPP wealth data to the

\footnotetext{
${ }^{1}$ Households are interviewed several times over a period of about two and a half years. Every "wave" collects core data on income, demographics, and other items. We use this information and data from periodic topical modules with information on 401(k) plans, assets and debt. The 1984 SIPP wave 4 was undertaken between September and December 1984. We refer to this as 1984 data. The 1985 SIPP wave 7 and the 1986 SIPP wave 4 surveys occurred between January and April 1987. Variables in these two samples have similar distributions, so we pool these data sets to form our 1987 data. Interviews for the 1990 SIPP wave 4 occurred between February and May 1991; we refer to this as 1991 data.
}

${ }^{2}$ The reference person is the person in whose name the family's home is owned or rented. If jointly owned or rented, either spouse may appear as the reference person.

${ }^{3}$ The SIPP records holdings of particular assets for each person in the household, and also provides summary data at the household level for holdings of classes of assets. We exclude households for whom these two sources of data do not match.

${ }^{4}$ In 1991, the raw sample contained 20,329 families. The sample totaled 11,948 after excluding families with no workers or with self-employed workers, 10,651 after excluding families with a reference person older than 64 or younger than 25, and 10,266 after excluding those with inconsistent asset data. Similar patterns occur for the other sample years. See Engen and Gale (1995, Appendix table 1).

${ }^{5}$ The top code for mortgages is $\$ 100,000$ in 1984 and 1987 , and $\$ 150,000$ in 1991 . For house value, the top code is $\$ 200,000$ in 1984 and 1987 , and $\$ 300,000$ in 1991 . Top coding affects only 3.3 percent or less of the sample in each year. 
Survey of Consumer Finances and the Panel Study of Income Dynamics. They conclude (p. 474) that the "striking feature of these comparisons is the substantial similarity in the amounts and distribution of wealth holdings across the three surveys--provided one ignores households with extremely high wealth (in excess of \$0.5 million)." High-income, high-wealth households are under represented in the SIPP. For analyzing 401(k)s, however, this limitation is not critical, because 401(k) eligibility is distributed widely across the population and contributions are capped. But the under-representation of high-income households may nevertheless prove important, if the effects of $401(\mathrm{k}) \mathrm{s}$ vary by earnings class. We return to this theme below.

We consider a family to be eligible for a 401(k) if either the reference person or the spouse works for an organization that offers a 401(k) plan to its employees. ${ }^{6}$ Because our data lack information on $401(\mathrm{k})$ contributions, a family is defined as a $401(\mathrm{k})$ participant if the reference person or spouse is eligible and has a positive 401(k) balance. We define financial assets to include checking accounts, U.S. saving bonds, other interest-earning accounts in banks and other financial institutions, other interest-earning assets (such as bonds held personally), stocks and mutual funds, and IRA, Keogh, and 401(k) balances. Net financial assets are defined as financial assets less unsecured debt. Housing equity is the defined as the difference between the value of the primary residence and outstanding mortgage debt against the principal residence, including second and third mortgages and home equity loans. We define wealth as the sum of housing equity and net financial assets. This broad wealth measure omits business wealth, but since the sample excludes the selfemployed, this is a natural restriction to impose. The wealth measure also excludes defined benefit pension rights and balances in non-401(k) defined contribution plans. We discuss the likely bias created by this omission in subsequent sections. Family earnings are given by the sum of the reference person and, if present, the spouse.

${ }^{6}$ Strictly speaking, plans authorized by section $401(\mathrm{k})$ of the Internal Revenue Code are only available to employees of for-profit firms that offer such plans. Employees of non-profit institutions and federal, state and local governments are eligible for similar saving plans authorized under different section codes. In this paper, we refer to all of these plans as $401(\mathrm{k}) \mathrm{s}$. 
With these definitions in mind, we highlight five patterns in the data to help motivate and frame the analysis below. First, at each point in time, eligibility for 401(k)s rises substantially with family earnings (table 1). Conditional on eligibility, participation rates also rise with earnings, but by smaller amounts. As a result, the share of all families that participates in a 401(k) rises dramatically with family earnings. For example, in 1991, 14 percent of families with earnings between $\$ 10,000$ and $\$ 20,000$ participated in a 401(k), compared to 51 percent of families with earnings above $\$ 75,000$. The wide divergence in $401(\mathrm{k})$ participation patterns suggests the impact of 401(k) eligibility on wealth may vary across earnings classes.

Second, eligibility and participation rates rose significantly between 1984 and 1991 (table 1). About 15 percent of families in the sample were eligible in 1984, rising to 38 percent by 1991 . Over the same period, the proportion of all families participating rose from 8.5 percent to 27 percent. The rapid expansion in 401(k) coverage and participation raises questions regarding the comparability of samples of eligible and ineligible households at a point in time and over time.

Third, 401(k) balances are concentrated among the highest earners and families that save in non401(k) forms (table 2). In 1991, about 70 percent of 401(k) balances and saving incentive balances (the sum of 401(k)s, IRAs, and Keoghs) were held by households with earnings above $\$ 40,000$. Households that have IRAs or Keoghs held over half of 401(k) balances and 75 percent of saving incentive balances. Homeowners held 88 percent of $401(\mathrm{k})$ balances and the same percentage of saving incentive balances. This suggests that the effect of 401(k)s among high-income and high-saver households will be a crucial determinant of the aggregate effect of $401(\mathrm{k}) \mathrm{s}$ on wealth.

Fourth, eligible households as a group have very different economic characteristics than ineligible households as a group at a point in time. In 1984, for example, median earnings among eligible families were almost $\$ 41,000$ (in 1991 dollars), compared to only $\$ 28,000$ among ineligible families. Table 3 shows that about 52 percent of eligible families had earnings above $\$ 40,000$, compared to 27 percent of ineligible families. Median net financial assets were $\$ 3,500$ for eligibles and $\$ 350$ for ineligibles, and median wealth 
was over $\$ 47,000$ for eligibles and below $\$ 21,000$ for ineligibles. These differences suggest that ineligible households as a group may not be a good control group for eligible households. An economic shock that had differential effects across earnings groups would also have differential effects on eligibles as a group relative to ineligibles. Thus, it could be mis-interpreted as an effect of $401(\mathrm{k}) \mathrm{s}$.

There are other systematic differences between eligibles and ineligibles as a group in 1984 (table 3). Among eligibles, 77 percent owned their homes, 75 percent were married, and 33 percent had an IRA or Keogh plan. Among ineligible households, the corresponding figures were markedly lower: 63 percent, 64 percent, and 22 percent. Similar differences occur in 1987 and 1991. These differences reinforce the notion that the groups of eligible and ineligible households have different characteristics and that ineligibles as a group are a poor control for eligibles as a group.

Fifth, after controlling for earnings, however, eligible households are much more similar to ineligible households at a given point in time and over time (table 3). Average earnings, of course, are essentially the same within earnings categories for eligibles relative to ineligibles in a given year. Within earnings groups, the average difference between eligibles and ineligibles in 1984 in the likelihood of owning an IRA or Keogh or a home is only one-fourth to one-half as large as the difference between the groups as a whole. The average difference in marital status is essentially zero. Similar patterns also hold for later years in the sample.

These findings suggest that although the characteristics of the overall sample of eligibles and ineligibles are different at a point in time and have changed over time, the characteristics of the two groups within earnings classes are much more similar--though clearly not identical--and have changed in much smaller and less systematic ways over time. This suggests that ineligible households in a particular earnings class may be a good control group for eligible households in the same earnings class.

\section{Previous Research}

Because our econometric specification is an effort specifically to resolve problems found in earlier 
work, we highlight key aspects of earlier work here and summarize the findings in table 4 . The effects of 401(k)s on saving are surveyed more broadly in Bernheim (1997, 1999), Engen, Gale and Scholz (1996a, 1996b), Hubbard and Skinner (1996), and Poterba, Venti and Wise (1996a, 1996b).

\section{A. Analysis of cross-section data}

A key issue in the analysis of 401(k) plans is how best to control for heterogeneity in tastes for saving across different groups and over time that may be correlated with $401(\mathrm{k})$ eligibility and participation. One approach to this problem has been to use cross-sectional variation in eligibility for $401(\mathrm{k}) \mathrm{s}$. In this test, the effects of $401(\mathrm{k}) \mathrm{s}$ are identified by the assumption that $401(\mathrm{k})$ eligibility is uncorrelated with tastes for saving, after controlling for certain factors. If eligibility is exogenous with respect to tastes for saving, then higher financial assets for eligibles relative to ineligibles would imply that $401(\mathrm{k}) \mathrm{s}$ raise saving.

Poterba, Venti and Wise (1995) test for the exogeneity of eligibility with respect to tastes for saving, after controlling for earnings. They use the 1984 SIPP cross-section of eligibles and ineligibles and estimate a median regression of the form:

$$
W_{j}=\alpha+X \beta+\Sigma_{k=2}^{6}\left(\gamma_{k} * Y_{j k}\right)+\Sigma_{k=1}^{6}\left(\delta_{k} * Y_{j k} * E L I G_{j}\right)+u_{j}
$$

In this specification, $\mathrm{W}$ is financial assets excluding 401(k)s and IRAs, $\mathrm{X}$ includes dummies for age group, educational attainment, and marital status, $\mathrm{Y}_{\mathrm{k}}$ indexes the same earnings groups as in tables 1-3, ELIG is an indicator for 401(k) eligibility, and $\mathrm{j}$ indexes households.

They find that the coefficients $\delta_{\mathrm{k}}$ in (1) are economically small and statistically insignificant. They interpret this result as showing that eligible and ineligible households had similar tastes for saving in 1984, at the outset of the $401(\mathrm{k})$ program, and therefore that eligibility is exogenous with respect to tastes for saving in each earnings category. They then employ cross-sectional regressions for 1987 and 1991 to show that, in each earnings category, eligible households in those years held more total financial assets than ineligibles did 
and did not have lower levels of non-saving incentive financial assets. They conclude that $401(\mathrm{k}) \mathrm{s}$ were net additions to wealth.

The advantage of this test is its simplicity. But there are several problems, too. Most importantly, the test compares the wrong set of assets. The appropriate way to determine whether eligible and ineligible households have similar tastes for saving requires a comparison of (a) the wealth of ineligible households and (b) the wealth of eligible households if they had not been eligible. For example, if $\mathrm{z}$ is the proportion of 401(k) balances that would have been saved even in the absence of the program, then the correct wealth measure to use for eligible households in the test above is the sum of non-401(k) wealth plus z times the household's 401( $k$ ) balances. Poterba, Venti, and Wise implicitly assume that $\mathrm{z}$ is equal to zero. That is, they assume that all 401(k) balances are net saving. Clearly, this creates a bias in favor of understating the correlation between eligibility and tastes for saving and overstating the effects of $401(\mathrm{k}) \mathrm{s}$ on saving. ${ }^{7}$

A second concern is that the Poterba, Venti, and Wise (1995) test ignores non-401(k) pension wealth. In preliminary work, Engelhardt (1999) uses the 1992 Health and Retirement Study and replicates the finding that eligible households hold more total financial assets than ineligibles. However, he also finds that once non- $401(\mathrm{k})$ pension wealth is included, there is no significant difference in the wealth of eligible and ineligible households by earnings category. These and other concerns (see Bernheim and Garrett 1995 and Engen, Gale, and Scholz 1996a, 1996) suggest that, although controlling for earnings at a point in time makes eligible and ineligible households look more similar than otherwise, it does not provide sufficient control to remove all residual differences in tastes for saving. ${ }^{8}$

${ }^{7}$ A potential response to this criticism is that, at the beginning of the 401(k) program in 1984, typical 401(k) were likely to be small. This response, however, ignores an important fact: most early 401(k)s were not new plans per se, but rather conversions of long-standing after-tax thrift plans. Thus, for example, in the 1983 Survey of Consumer Finances, the median balance in thrift plans among participants was \$3,700 (Engen, Gale and Scholz 1996b).

${ }^{8}$ Benajmin (2000) uses the 1991 SIPP to estimate the cross-sectional effects of 401(k) eligibility on wealth controlling for a very long list of economic and demographic characteristics. His results are discussed in detail later in the paper. 


\section{B. Tests using Successive cross-sections of "Like families" or "Similar saver groups"}

\section{(1) Tests Comparing Financial Assets Over Time for Eligible Families Only}

Poterba, Venti, and Wise (1995) propose a second approach as well. This test compares how asset balances evolve over time for successive cross-sections of "similar savers"--for example, eligible households. In this test, the effects of $401(\mathrm{k}) \mathrm{s}$ are identified by the assumption that the only significant difference between the samples of eligible households in earlier and later years is that eligible households in later years have had increased years of exposure to 401(k)s (and IRAs). Thus, if eligible households in later years have higher financial assets than those in earlier years, controlling for household characteristics, the conclusion would be that $401(\mathrm{k}) \mathrm{s}$ raise saving.

To implement this test, Poterba, Venti, and Wise use the sample of eligible households only in 1984, 1987, and 1991, and specify an equation of the form:

$$
W_{j}=\alpha_{E}+X_{j} \beta_{E}+\Sigma_{K=2}^{6}\left(\gamma_{E k} * Y_{j k}\right)+\delta_{E 84} * I N 84_{j}+\delta_{E 91} * I N 91_{j}+u_{E j} \cdot
$$

In this specification, $\mathrm{X}$ and $\mathrm{Y}$ are defined as in (1), and IN84 and IN91 are indicator variables showing whether the household is in the 1984 or 1991 samples, respectively. At the risk of oversimplifying, the main findings are: when $\mathrm{W}$ represents non-saving incentive financial assets, $\delta_{\mathrm{E} 84}$ and $\delta_{\mathrm{E} 91}$ are approximately zero; when W represents total financial assets, $\delta_{\mathrm{E} 91}$ is positive and significant (and the 1984 sample is excluded due to missing 401(k) balance data). Given the identifying restrictions, these results suggest that $401(\mathrm{k}) \mathrm{s}$ raise private saving and do not reduce other saving.

A significant advantage of this approach is that it does not require that eligibles and ineligibles have similar tastes for saving. However, there are problems, too. First, the test assumes that average tastes for saving among eligible households are constant over time. In fact, average tastes could have risen or fallen among eligibles and thus biased the test in either direction. We investigate this issue in section $\mathrm{V}$. 
Second, the identifying restriction that no other relevant factors changed between 1984 and 1991 is simply implausible. Briefly, during this period, the stock market boomed, real interest rates were high relative to previous years, social security benefits were cut back significantly in the 1983 reforms, and defined benefit pension coverage fell significantly (see Engen, Gale and Scholz 1996a). In addition, the decline in inflation and in marginal tax rates over this period caused a shift in value from real assets, such as housing, toward financial assets (See the analysis in Feldstein 1980, Summers 1981, and Poterba 1984). Finally, between 1984 and 1991, aggregate financial assets rose by $\$ 4$ trillion whereas saving incentive balances rose by about $\$ 1$ trillion (Engen, Gale, and Scholz 1996a). Thus, something other than saving incentives must have been boosting financial assets. The existence of these non-401(k) factors makes the "similar savers" test based only on the results for eligibles difficult to interpret, and surely biased toward overstating the impact of 401(k)s on saving. ${ }^{9}$

Third, the test assumes that the additive impact of $401(\mathrm{k}) \mathrm{s}$ on wealth is the same in each earnings class. However, most participants contribute similar proportions of their salary to 401(k)s, making it plausible that the additive effect would vary across earnings groups over time.

\section{(2) Tests Comparing Financial Assets Over Time for Eligible and Ineligible Families}

One way to address the problems created by examining only eligible families over time is to use ineligible families over time as a control group. In this test, the effects of $401(\mathrm{k}) \mathrm{s}$ are identified by the assumption that nothing that changed over the sample period had a differential impact on the group of eligibles relative to the group of ineligibles. Thus, if assets rose more for eligibles over time than for ineligibles, the difference would be interpreted as the positive effect of 401(k)s on wealth accumulation.

To implement this test, Poterba, Venti, and Wise (1995) estimate regressions with the same form as

\footnotetext{
${ }^{9}$ On the other hand, one might argue that the declining official personal saving rate over this period would work in the opposite direction and serve to reduce financial assets. However, the official personal saving rate badly mismeasures changes in wealth--which are the focus of this study--and in particular omits capital gains, which were large during this period. See Gale and Sabelhaus (1999).
} 
(2), but for samples of ineligible households:

$$
W_{j}=\alpha_{I}+X_{j} \beta_{I}+\Sigma_{K=2}^{6}\left(\gamma_{I k} * Y_{j k}\right)+\delta_{I 84} * I N 84_{j}+\delta_{I 91} * I N 91_{j}+u_{I j}
$$

where variables are defined analogously to equation (2) and $\mathrm{W}$ represents non-saving incentive financial assets. They find that $\delta_{\mathrm{I} 84}$ and $\delta_{\mathrm{I} 91}$ are approximately zero. Thus, the result of separately estimating (2) and (3) is that financial assets rose for eligibles as a group over this period, but did not rise for ineligibles as a group. Poterba, Venti, and Wise (1995) interpret this finding as evidence that 401(k)s have raised saving. This is clearly a stronger test than any based only on samples of eligibles over time, but it is still problematic. First, as with tests based only on eligible households, one concern is whether average tastes for saving changed over time. But for this test, the relevant question is whether average tastes for saving changed for eligible households relative to ineligible households. This issue is discussed in section V.

Second, a test comparing the effects of estimating (2) on eligibles and (3) on ineligibles measures the impact of 401(k)s with a single coefficient for each year. But as shown above, eligibles as a group started the sample period with higher earnings, financial assets, and wealth than ineligibles did. Thus, any change that is not controlled for and that raised all financial assets by the same proportionate amount would have increased financial assets by a larger arithmetic amount for eligibles than for ineligibles. This would appear, in (2) and (3), as a larger effect over time for eligibles relative to ineligibles, but would not be due to 401(k)s. Thus, for example, the stock market boom, or proportionate shifts in the allocation of wealth from real assets to financial assets would lead to spurious increases in financial assets for eligibles relative to ineligibles. Likewise, any change that aided high-earnings households relative to low-earners would have similar spurious effects. For example, the well-documented widening of the income distribution helped high-earners relative to low-earners. The stock market boom did as well, because high-earning households are more likely to hold stocks and hold a larger share of their portfolio in stocks (Poterba and Samwick 1999) than low-earning 
households.

A third concern is that this test, like the one for eligible households described above, assumes that the effect of 401(k)s on wealth is the same across all earnings classes. This clearly need not be the case.

\section{(3) Tests Comparing Wealth Over Time for Eligible and Ineligible Families}

In earlier work (Engen and Gale 1997, tables 5-7 and 11-13), we estimate (2) and (3) on net financial assets and on broader measures of wealth that include housing equity. Our results generally confirmed the Poterba, Venti, and Wise (1995) finding; net financial assets rose more for eligibles as a group than for ineligibles. These results, of course, are subject to the same problems as those noted above. We also found, however, that broader wealth measures that included housing equity did not rise for eligibles relative to ineligibles. We concluded that the impact of $401(\mathrm{k}) \mathrm{s}$ on household wealth--as opposed to financial assets-was minimal.

These results have been criticized on several grounds. First, there is concern about how average tastes for saving among eligibles evolved over time relative to ineligibles (Bernheim 1997). Second, Poterba, Venti, and Wise (1996a, 1996b) note that at the beginning of the sample period, eligibles as a group had higher housing wealth than ineligibles did. During the sample period, especially 1987-91, they argue that there were equal percentage declines in housing wealth among eligibles and ineligibles, due to housing market factors that are completely unrelated to 401(k)s. However, because eligibles started out with higher housing wealth, they had a larger arithmetic decline in their housing wealth. This shows up as a reduction in wealth for eligibles relative to ineligibles, because Engen and Gale (1997) use wealth levels as the dependent variable, but should not be interpreted as an offset to $401(\mathrm{k})$ wealth. ${ }^{10}$

${ }^{10}$ Engen and Gale (1997, tables 4-6 and 8-10) also estimate a single equation model of the form:

$$
W_{j}=\alpha+X \beta+\Sigma_{k=2}^{6}\left(\gamma_{k} * Y_{j k}\right)+\delta_{1} * E L I G_{j}+\delta_{2} * I N 91_{j}+\delta_{3} * E L I G_{j} * I N 91_{j}+u_{j} \text {. }
$$

The impact of $401(\mathrm{k}) \mathrm{s}$ is given by $\delta_{3}$. This approach, however, combines the coefficient estimates for eligibles and ineligibles, which is not a valid restriction if tastes for saving differ across groups. Appendix Tables 1 and 2 show that this restriction is rejected by the data. Recent analyses by Sabelhaus and Ayotte (1998) and Pence (2000) employ the specification above and thus are subject to the same critique. 


\section{(4) Summary, reconciliation, and new directions}

Remarkably, the criticisms of the Engen and Gale (1997) estimates, which use wealth including housing equity as the dependent variable, almost exactly parallel the criticisms of the Poterba, Venti and Wise (1995) estimates, which use financial assets as the dependent variable. In each case, the argument is that (a) eligibles as a group began the sample period with higher earnings and wealth than ineligibles, and (b) outside factors caused changes in wealth across earnings classes that ended up being confused with the impact of 401(k)s. The outside factors caused financial assets to grow in arithmetic terms for high-earners relative to low-earners over this period, leading Engen, Gale and Scholz (1996a, 1996b) to argue that tests of (2) and (3) using financial assets overstated the impact of 401(k) plans. In contrast, other outside factors caused housing wealth to fall in arithmetic terms for high-earners relative to low-earners, leading Poterba, Venti and Wise (1996a, 1996b) to argue that tests using (2) and (3) that used broad wealth measures that include housing understated the impact of 401(k)s.

Two simple changes to (2) and (3) can resolve these problems. First, to separate the effects of 401(k) eligibility from changes in other factors that affect wealth and that have different effects at different earnings levels, the effects of eligibility should be examined within each earnings class rather than for the group as a whole. For example, Poterba, Venti, and Wise (1996b, page 54) indicate that, despite large differences in housing equity between the typical eligible and the typical ineligible household, "within income intervals, the differences are typically small." Second, to remove the impact of factors that cause equiproportionate changes in wealth for different groups over time, analysis should examine the effects of 401(k)s on log wealth rather wealth levels. These are two of the significant changes to our previous analysis that we introduce below.

\section{Modeling 401(k)s and Wealth Accumulation}

We develop our econometric model in several steps. First, we eliminate the 1984 data from 
consideration since the SIPP does not provide information on 401(k) balances in that year. Thus, we drop the IN84 terms in equations (2) and (3). Second, we expand (2) and (3), which estimate wealth for eligibles and ineligibles separately, to allow the coefficient on IN91 to vary by earnings class:

$$
\begin{aligned}
& W_{j}=\alpha_{E}+X_{j} \beta_{E}+\Sigma_{k=2}^{6}\left(\gamma_{E k} * Y_{j k}\right)+\Sigma_{k=1}^{6}\left(\delta_{E k} * I N 91_{j} * Y_{j k}\right)+u_{E j}, \text { and } \\
& W_{j}=\alpha_{I}+X \beta_{I}+\Sigma_{k=2}^{6}\left(\gamma_{I k} * Y_{j k}\right)+\Sigma_{k=1}^{6}\left(\delta_{I k} * I N 91_{j} * Y_{j k}\right)+u_{I j}
\end{aligned}
$$

Third, we multiply (4) by the eligibility indicator and (5) by 1- the eligibility indicator and combine the equations to yield our central specification:

$$
\begin{aligned}
W_{j} & =\alpha_{I}+\left(\alpha_{E}-\alpha_{I}\right) * E L I G_{j}+X \beta_{I}+X_{j}\left(\beta_{E}-\beta_{I}\right) * E L I G_{j} \\
& +\Sigma_{k=2}^{6}\left(\gamma_{I k} * Y_{j k}\right)+\Sigma_{k=2}^{6}\left(\gamma_{E k}-\gamma_{I k}\right) Y_{j k} * E L I G_{j} \\
& +\Sigma_{k=1}^{6}\left(\delta_{I k} * I N 91_{j} * Y_{j k}\right)+\Sigma_{k=1}^{6}\left(\delta_{E k}-\delta_{I k}\right) * I N 91_{j} * Y_{j k} * E L I G_{j}+u_{j} .
\end{aligned}
$$

In (6), $\mathrm{W}$ measures wealth, $\mathrm{X}$ is a vector of demographic variables, $\mathrm{Y}_{\mathrm{k}}$ indexes earnings categories, IN91 indicates if a household is in the 1991 sample, and ELIG shows if the household is eligible for a 401(k).

Estimating (6) will yield the same coefficients as estimating (4) for eligibles and (5) for ineligibles and then differencing the results. ${ }^{11}$ Also, (6) generalizes specifications used in earlier work. The successive cross-section analyses outlined above assume that $\delta_{\mathrm{Ek}}=\delta_{\mathrm{E}}$ and $\delta_{\mathrm{Ik}}=\delta_{\mathrm{I}}$ for all earnings groups $\mathrm{k}$. Some other features of this specification are worth discussing in more detail.

\section{A. Control group}

\footnotetext{
${ }^{11}$ In practice, the standard errors would be slightly different, because (5) imposes the assumption that $\sigma_{E}=\sigma_{I}$, where $\sigma_{E}$ and $\sigma_{I}$ represent the standard deviations of the error terms in equations (4) and (5) respectively.
} 
The key coefficients in (6) are $\delta_{\mathrm{Ek}}-\delta_{\mathrm{Ik}}$, which indicate how much wealth increased in each earnings class from 1987 to 1991 for eligible households relative to ineligible households. Thus, the control group for eligibles is ineligibles in the same earnings class. There are several advantages to using this control group. Two reasons were noted above. Eligibles and ineligibles have similar--though clearly not identical-economic and demographic characteristics after controlling for earnings, and changes that are uncontrolled for and that have differential effects across earnings classes will not bias the results in this specification. There are several additional reasons, though, to isolate effects of $401(\mathrm{k}) \mathrm{s}$ by earnings class. First, the rate and level of saving appear to vary across earnings groups (Dynan, Skinner, and Zeldes 2000, and Hubbard, Skinner, and Zeldes 1995). In addition, the constraints that savers face--for example, government means-testing rules or tax rates and other rules--typically vary by earnings classes. Allowing for different effects of $401(\mathrm{k}) \mathrm{s}$ by earnings group will control for these effects, as long as they do not differ between eligibles and ineligibles within an earnings category. Second, the ability to substitute other assets into a 401(k) or to finance contributions with debt may vary across earnings classes, since high-earning households tend to have higher wealth. Third, to the extent that participants contribute similar percentages of their salary to $401(\mathrm{k}) \mathrm{s}$, the effects of 401(k)s on wealth will vary with earnings.

\section{B. Narrow versus Broad Measures of the Dependent Variable}

We consider the impact of $401(\mathrm{k}) \mathrm{s}$ on both net financial assets and wealth (net financial assets plus housing equity). In the aftermath of TRA 1986, which eliminated interest deductions on non-mortgage consumer debt, high-income households switched their portfolios toward increased mortgage debt and reduced non-mortgage debt (Maki 1999). A study that examined only net financial assets would mistake this shift in the composition of debt for an increase in net financial assets. In addition, for the typical household, financial assets are a small fraction of net worth. ${ }^{12}$ Thus, an investigation of the effect of $401(\mathrm{k}) \mathrm{s}$ only on net

\footnotetext{
${ }^{12}$ In our sample, mean household financial assets were 25 percent of mean net worth in 1984 and rose to 33 percent in 1991. Median holdings of financial assets were 7 percent of median net worth in 1984 and rose to 13 percent in 1991. Aggregate data follow similar trends, with financial assets an even higher proportion
} 
financial assets would miss many potential sources of substitution.

Substitution between housing wealth and 401(k) plans should not be surprising. Both types of taxfavored assets are relatively illiquid and typically held for a long period. In addition, there are strong financial incentives for households to substitute and thus diversify their tax-preferred portfolio. Employer matching of 401(k) contributions implies that financing a 401(k) with tax-deductible mortgage borrowing can be quite lucrative. ${ }^{13}$ Even if households are not consciously gaming the tax system, there could still be substitution between 401(k)s and home equity that is unintentional. Consider different cohorts of new homeowners who are observationally equivalent except that the new homeowners in the later year have had longer exposure to $401(\mathrm{k}) \mathrm{s}$ and so have placed more funds in $401(\mathrm{k}) \mathrm{s}$ than did those in the younger cohort. Now suppose that households in the later cohort have smaller balances of liquid cash (because they have moved more of their liquid cash into 401(k)s) than those in the earlier cohort). Because they have less cash available, households in the later cohort might purchase the same size home as the earlier cohort, but with a larger mortgage. A comparison of households in these two cohorts would reveal that households in the later cohort had less housing equity, more 401(k) wealth, but the same overall wealth compared to households in the younger cohort. As an analytical statement, households in the later cohort were clearly substituting 401(k)s for home equity relative to earlier cohorts, even if this substitution were completely unintentional and even if the household itself were unaware of the comparison. Similar types of "inadvertent" substitution could be quite widespread. ${ }^{14}$

of net worth because financial assets are heavily concentrated among the very wealthiest households, which are under represented in our data set.

${ }^{13}$ See Engen, Gale and Scholz (1996b). Simple calculations show that with typical employer matching contributions, workers should do everything possible to maximize $401(\mathrm{k})$ contributions at least up to the match limit. Kusko, Poterba, and Wilcox (1994) report that about 75 percent of 401(k) participants in their sample at one firm contributed at or above the match limit.

${ }^{14}$ As Stiglitz (1988, p. 595) notes: "The individual may, of course, not consciously perceive himself as borrowing for these purposes; he may say to himself in April that it would be a good idea to put money into an IRA; and then in June, he may decide that he would like to buy a new car; given his available cash, he 
It is also worth noting that between about 14 percent of eligible homeowners had home equity loans in 1991; about 19 percent bought new homes between 1987 and 1991; and a reasonable estimate is that 12 percent extracted equity from their home via a refinancing between 1987 and 1991 (Bernheim 1997). Thus a significant portion of eligible families had direct access to ways to change in home equity.

\section{Functional Form of the Dependent Variable}

We estimate models with four different functional forms of the dependent variable: the level of wealth; the ratio of wealth to earnings; and the natural log of these two values. We use wealth levels to compare to previous research. Using wealth-earnings ratios, however, is a natural way to control for the effects of 401(k)s if participants at different earnings levels tend to contribute similar percentage of their salary to 401(k)s. In addition, using the wealth-earnings ratio helps control for any variation in earnings over time within earnings categories. Finally, in detailed dynamic saving models (see, for example, Hubbard, Skinner, and Zeldes 1995, Samwick 1995, Laibson, Repetto, and Tobacman, 1998, or Engen, Gale, and Uccello 1999) implications often can be drawn as readily with regard to wealth-earnings ratios as with regard to wealth levels.

The justification for estimating log wealth and log wealth/earnings ratios stems from the combination of two issues. First, eligibles and ineligibles start the sample period with different assets, even within earnings groups. This suggests that there may be still differences in tastes for saving between the two groups, even after controlling for earnings. Second, if the groups begin the sample with different wealth levels, market forces that cause assets to rise or fall by a constant percentage rather than by a constant amount will create spurious effects for a specification that controls for wealth levels or wealth/earnings ratios. ${ }^{15} \mathrm{~A}$

finds that he needs to borrow more than he otherwise would have."

${ }^{15}$ Suppose 401(k)s have no effect on saving, and consider an eligible household (E) in year 1 with wealth of 100, and an ineligible household (I) with lower tastes for saving and hence wealth of 50. (Assume the two households have equal earnings.) If market forces raise all asset values by 20 percent in one period, then $\mathrm{E}$ will have wealth of 120 and I will have 60. A difference-in-difference estimate using wealth levels would show that E's wealth rose by 10 more than I's. By construction, however, this effect is not due to 401(k)s. 
natural way to control for percentage changes is by using log wealth. ${ }^{16}$

\section{Explanatory Variables}

Dynamic models with earnings uncertainty (see Hubbard, Skinner, and Zeldes 1995, Samwick 1995, Laibson, Repetto, and Tobacman 1998, and Engen, Gale, and Uccello 1999) do not generate closed-form solutions for wealth. However, the results show clearly that wealth or wealth/earnings ratios should evolve as a function of age (for life-cycle reasons), education (as a proxy for the slope of the age-earnings profile and/or tastes for saving), earnings (because social security, welfare programs, and income taxes are progressive), and marital status (as a proxy for family size). All of these are controlled for in all previous studies of 401(k)s. In addition, theory and evidence suggests that pension coverage, family size, the presence of two earners and taste-shifters relating to race and sex of the household head should affect saving as well. We thus include all of these as right-hand side regressors.

All of the explanatory variables other than family size are expressed are indicator variables. For age, the categories are 35-44, 45-54, and 55-64, with 25-34 being the omitted category. For education, the categories are 12 years, 13-15 years, 16 years, and more than 16 years, with less than 12 years as the omitted category. For earnings, we use the categories listed in tables 1-3, but we exclude all households with earnings less than $\$ 10,000$ from the regressions because of data irregularities. This should have minimal impact on the results since these households account for only 1 percent of $401(\mathrm{k})$ balances. The regressions omit the $\$ 10,000-\$ 20,000$ earnings category as an explanatory variable.

\section{Results}

\section{A. Descriptive data on asset changes by eligibility status and earnings group}

Likewise, if the market fell by 20 percent, E's wealth fall by 10 relative to I, but this would not be evidence that $401(\mathrm{k}) \mathrm{s}$ reduced saving.

${ }^{16}$ Pence (2000) explicitly recognizes these issues and proposes the use of inverse hyperbolic sine transformation of wealth, rather than the log, to resolve the problem. 
Table 5 shows how median wealth measures evolved from 1987 to 1991 for eligible households relative to ineligible households by earnings class. For eligibles as a whole, median 401(k) balances rose by $\$ 1,214$. In earnings groups above $\$ 30,000$, median $401(\mathrm{k})$ balances rose by between $\$ 1,700$ and $\$ 6,000$. Thus, there was a substantial increase in median 401(k) balances during this period, especially in higher earnings groups. Median balances in saving incentive accounts rose by similar amounts.

Net financial assets rose for eligibles relative to ineligibles in middle- and upper-income groups, but not for the highest earnings group. Other than saving incentive balances, financial assets fell for eligibles relative to ineligibles in most groups. House value rose for eligibles relative to ineligibles within earnings groups, but mortgage debt rose even more--especially in high-earnings groups--so that housing equity fell for eligibles relative to ineligibles in three of the six groups and on an overall basis. Median wealth rose for eligibles relative to ineligibles in most earnings groups, but fell for eligibles as a whole compared to ineligibles.

\section{B. Replication and Extension of Earlier Work}

Table 6 replicates and extends earlier estimates by Poterba, Venti and Wise (PVW, 1995). The explanatory variables include only variables used in their study: indicators for age, education, earnings, and marital status, and whether the household is in the 1991 sample. Poterba, Venti, and Wise (1995) report analytical standard errors. Monte Carlo tests suggest that, in the presence of heteroskedasticity, bootstrapped standard errors provide more reliable estimates than analytical standard errors (Rogers 1992). We present results using both approaches. Items in parentheses in the tables represent $t$-statistics using analytical standard errors. Items in square brackets represent t-statistics using bootstrapped standard errors (with 200 replications). ${ }^{17}$

We begin by estimating (2) for eligibles. When the dependent variable is net financial assets, we estimate that $\delta_{\mathrm{E} 91}=\$ 1,190$ (with $\mathrm{t}=2.91$ ), the first entry in table 6. Median 401(k) balances among eligibles

\footnotetext{
${ }^{17}$ Pence (2000) provides further discussion of alternative methods of generating standard errors.
} 
increased by $\$ 1,214$ over this period (table 5), so the estimate in table 6 suggests that all $401(\mathrm{k})$ contributions were new saving, which is consistent with the results and interpretation given in PVW (1995). If the dependent variable is financial assets excluding saving incentives, we obtain $\delta_{\mathrm{E} 91}=-\$ 600(\mathrm{t}=3.41)$, suggesting a drop in other financial assets. For ineligible households, we estimate (3) and find that $\delta_{\mathrm{I} 11}$ is approximately zero. These results are similar to PVW (1995, Table 5).

The next step is to allow the effects of $401(\mathrm{k}) \mathrm{s}$ to vary by earnings class over time. The results of estimating (4) for eligibles with the dependent variable equal to net financial assets is given in the first row of table 6 in the 2 nd- 7 th columns. The $\delta$ coefficients are positive in each income class. Using the analytical standard errors, the results are significant only in the top two earnings groups. More importantly, an F-test easily rejects the view that the coefficients are all equal across earnings classes. The test statistic is 6.23 , whereas the 1 percent critical value for $\mathrm{F}(5,6407)$ is 3.02 . The huge increase in financial assets in the top earning group, $\$ 7,756$, is particularly notable and we return to this estimate below. The second row of table 6, columns 2-7, shows the same regression, but with wealth equal to non-saving incentive financial assets. The coefficients are uniformly negative, and the top three earnings groups have large and significant coefficients, using the analytical standard errors.

The next two rows of table 6 , columns $2-7$, show the same regressions for ineligible households. In the regression for financial assets, note the huge coefficient for the top income group $(\$ 7,223)$. This is essentially the same increase as for high-earning eligibles noted above and shows the importance of using a control group, rather than simply relying on tests for eligible households over time. Generally, there is no increase in financial assets for ineligible households by earnings group, except for the top group. An F-test generates a test statistic of 136 ( 1 percent critical value $=3.02)$, thus easily rejecting the view that the coefficients are equal across income class.

To compare the results for the eligible and ineligible households by earnings categories, we subtract the coefficients in row 3 and 4 from those in 1 and 2 and calculate the standard errors. These values 
are reported in the last two rows of the table and show positive but statistically insignificant increases for financial assets in all earnings groups except for households with earnings between $\$ 50,000$ and $\$ 75,000$, where the effect is positive and significant. The table shows economically and statistically significant declines in non-saving incentive financial assets in the top three earnings groups. All of the above discussion focuses on analytical standard errors, for comparison purposes with earlier work. Using the bootstrapped standard errors reduces the significance of almost all of the coefficients.

Thus, the results in table 6 generate several important findings. First, we are able to replicate the results in earlier literature using equation (2) and (3) that show that using only a single parameter to capture year effects will generate results that are consistent with the view that $401(\mathrm{k}) \mathrm{s}$ raise saving. Second, we show that the specification with a single parameter capturing year effects is statistically rejected in favor of a more general specification that allows the effects of $401(\mathrm{k}) \mathrm{s}$ to vary across earnings class and time. Third, we show that using the more general specification implies smaller impacts of $401(\mathrm{k}) \mathrm{s}$ on financial assets. Fourth, we show that using the bootstrapped standard errors reduces the significance of $401(\mathrm{k})$ effects further.

\section{Full Specification with Wealth Level as the Dependent Variable}

Table 7 provides estimates of (6) using wealth levels as the dependent variable. The estimates that employ analytical standard errors show that 401(k) eligibility has a positive and significant impact on financial assets in earnings groups between $\$ 30,000$ and $\$ 75,000$, and leads to economically significant reductions in non-saving incentives financial assets in earnings groups above $\$ 40,000$. Examining wealth (defined as net financial assets plus housing equity) suggests only one positive significant impact (in the $\$ 30,000-\$ 40,000$ earnings class). Examining non-saving incentive wealth suggests offsets in the top three earnings categories.

These results tell an interesting story, and one that is not completely consistent with either the earlier Poterba, Venti, and Wise (1995) or the Engen and Gale (1997) conclusions. In the top earnings group, there 
appears to be no impact of $401(\mathrm{k}) \mathrm{s}$ on financial assets or wealth, and a significant reduction in other assets due to $401(\mathrm{k}) \mathrm{s}$. In the next two groups--with earnings between $\$ 40,000$ and $\$ 75,000--401(\mathrm{k})$ eligibility is associated with higher financial assets, but not with higher wealth, and there is significant offset in both nonsaving incentive financial assets (row 2) and non-saving incentive wealth (row 4). The three top earnings groups account for about 70-80 percent of $401(\mathrm{k})$ balances in the two sample years (see table 2), and that in these groups there does not appear to be any positive effect of $401(\mathrm{k}) \mathrm{s}$ on wealth.

For households with earnings between $\$ 30,000$ and $\$ 40,000$, the estimated impact of $401(\mathrm{k}) \mathrm{s}$ on saving is as large as the increase in 401(k) balances for eligibles in this group (table 5), suggesting that all of the 401(k) balances in this group are net new private saving. This group accounts for about 11-16 percent of 401(k) balances in each year. For households with earnings between $\$ 10,000$ and $\$ 30,000$, the impact of 401(k) eligibility is hard to discern: wealth measures including 401(k)s generate positive but imprecisely estimated coefficients; wealth measures excluding 401(k)s generally generate negative but imprecisely estimated coefficients. Part of the problem undoubtedly is the relatively small change in $401(\mathrm{k})$ balances among eligibles in these groups (see table 5). These two groups contain 9-13 percent of 401(k) balances in each sample year.

Thus, the results in table 7 suggest that between 70 and 80 percent of $401(\mathrm{k})$ balances accrue in earnings groups where eligibility has no noticeable impact on wealth accumulation. Between 11 and 16 percent accrue in the earnings group where upwards of 100 percent of 401(k) balances appear to represent net additions to private saving. And the remaining 9-13 percent has an uncertain effect. Note, however, that even if all of the balances of households with earnings below $\$ 40,000$ were net saving, this would only account for between 25 and 29 percent of $401(\mathrm{k})$ balances.

In addition, note that all of these effects are based on the analytical standard errors. Using bootstraps generally reduces all of the t-statistics. (Only one of the coefficients in table 7 is even significant at the 10 percent level.) Appendix tables 1 and 2 report the full set of coefficient estimates for the specifications in 
table 7 using net financial assets and wealth as the dependent variables. The results indicate the economic and statistical significance of a wide range of explanatory variables, when entered alone and when interacted with eligibility.

Appendix table 3 provides similar estimates and generally similar results to table 7, but uses a robust regression technique. ${ }^{18}$ We have also estimated the equations using ordinary least squares (OLS). These estimates are perhaps suspect because they may be unduly influenced by outliers and saving is known to be quite heterogeneous across households. Nevertheless, the OLS estimates find no significant effects, except in the top earnings group where they show complete offset of $401(\mathrm{k})$ balances with reductions in other wealth.

\section{Estimates by Saver Group with Wealth Level as the Dependent Variable}

Table 8 provides median regression estimates similar to table 7 but with the sample broken down into separate groups based on saving status. The goal of this exercise is to help control for tastes for saving by isolating groups with similar propensities or similar opportunities to incur debt or shift assets. Thus, we stratify by IRA status and homeowner status.

Among households with IRAs, 401(k) eligibility has a positive but statistically insignificant effect on net financial assets. The impact on wealth is negative and insignificant in four of the six earnings categories, and positive and insignificant in two. An F-test does not reject the view that all of the wealth coefficients are zero. The test statistic is 0.61 , whereas the 5 percent critical value for $F(6,5143)$ is 2.80 .

For households without IRAs or Keoghs, the estimated effects on wealth are positive and significant for households with earnings between $\$ 30,000$ and $\$ 75,000$, and are as large as the change in $401(\mathrm{k})$ balances over time. Thus, plausibly all of these 401(k) balances represent net additions to private saving.

\footnotetext{
${ }^{18}$ The robust regression method is described in Stata (1993, volume 2, pp. 126-131). The first step is an ordinary least squares regression; outliers (i.e., any observation with Cook's D>1) are then excluded. The procedure then works iteratively: an ordinary least squares regression is run, weights are calculated based on the absolute residuals, and then those weights are used in estimating the next regression. This process continues until convergence is obtained in the successive estimates. The first set of weights used are Huber weights. Based on those results, biweights are then used until convergence is obtained. Both weights are used in order to offset potential problems with using either one or the other.
} 
These groups held between 26 and 33 percent of $401(\mathrm{k})$ balances in 1987 and 1991 . However, using bootstrapped standard errors, none of these effects are significant.

For homeowners, there is a strong positive significant impact of $401(\mathrm{k}) \mathrm{s}$ on financial assets in all earnings groups except the highest and the lowest, but there is no significant impact on wealth, and four of the six coefficients for wealth are actually negative. This is important because homeowners hold about 88 percent of 401(k) balances in each year of the sample. The effect for the top earnings group is clearly not positive. An F-test does not reject the hypothesis that all wealth coefficients in earnings groups below $\$ 75,000$ are zero (the test statistic is 0.27 , whereas the 1 percent critical value for $F(5,12434)$ is 3.02 ).

For renters, the effect of eligibility on net financial assets is positive and significant, and as large as the increase in 401(k) balances, in four earnings categories. These groups account for about 8 percent of 401(k) balances. In the other earnings categories, eligibility does not have a positive and significant effect.

In summary, separate estimates by saver status suggest that between 8 percent and 33 percent of 401(k) balances represent new private saving, using the analytical standard errors. This is consistent with the results in table 7, which provided estimates from 11-16 percent to 25-29 percent. The net saving effect is most likely to occur for households that have lower wealth, lower earnings or are renters.

\section{E. Other Functional Forms for Wealth}

Appendix Table 4 provides estimates with wealth measures divided by earnings as the dependent variable. Results are similar to those in tables 7 and 8 .

Specifications of the effect of eligibility on log wealth must confront the fact that a significant minority of households have zero or negative wealth. To address this issue, we proceed in several steps. First, we restrict the sample to age-education-earnings groups where more than 50 percent of households have positive net financial assets and positive net wealth. This turns out to include all age-education-earnings groups with earnings above $\$ 30,000$. These households account for at least 85 percent of all $401(\mathrm{k})$ balances (table 2) in each year. Second, rather than exclude households in these cells that have zero or negative net 
financial assets or wealth, we instead reassign their wealth to equal 1. By doing so, we retain valuable information about these households, but we do not alter the median wealth figures in each cell. If all of reassigned observations lie below the regression line, the LAD coefficient estimates for the sample with the reassigned values will be exactly the same as if the zero and negative wealth values could be used (Bloomfield and Steiger 1983). ${ }^{19}$ In theory, the standard deviations of the coefficient estimates will be the same as well. However, in the presence of non-continuous variables, such as the indicator variables in our regression, the standard deviations of the coefficients can vary in an apparently unbiased way. Third, to test the empirical effects of this transformation, we re-estimated the specifications in table 7 using wealth levels, but reassigning all negative and zero values of the dependent variables to 1 . This procedure generated the numerically identical set of estimated coefficients with standard deviations of the estimates that were about 50 percent larger.

Appendix table 5 presents estimates of the model using a log transformation of the wealth level. Table 9 estimates the model with the dependent variable being a log transformation of the wealth to earnings ratio. ${ }^{20}$ The results in the latter two tables are similar and we will focus on the estimates in table 9 using log (wealth/earnings).

For the whole sample with earnings above $\$ 30,000$, focusing on the analytical standard errors, table 9 shows a sizable effect of eligibility on financial assets for households with earnings between $\$ 30,000$ and $\$ 40,000$, but no significant effects for the higher income groups. The results also suggest a significant, albeit much smaller, increase for wealth for those earning between $\$ 30,000$ and $\$ 40,000$. Effects on wealth are positive but not significant for those with earnings between $\$ 40,000$ and $\$ 75,000$, and negative and insignificant for the highest earning group. The hypothesis that the impact on wealth in the top three earnings

\footnotetext{
${ }^{19}$ Johnson, Kitamura and Neal (2000) recently make use of this result, for example, to impute unobserved wages for unemployed individuals in median wage regressions.

${ }^{20}$ Before taking the log, we multiply the ratio of wealth to income by 50,000 to set the dependent variable at the same order of magnitude as in the log (wealth) specification.
} 
groups is zero cannot be rejected at conventional levels.

Analysis on sub-samples of households that have enough wealth to be considered for the log specification greatly reduces the impact of $401(\mathrm{k})$ eligibility. Recall that for the whole group earning between $\$ 30,000$ and $\$ 40,000$, eligibility was estimated to raise wealth by 24 percent. However, among IRA holders in that group, the effect falls to 0.6 percent and for homeowners the effect falls to 3.7 percent. In neither of the latter two cases is the effect significant. For the higher-income groups with IRAs or with a home, the effects are generally small and not different from zero. Thus, results using log wealth/earnings as the dependent variable suggest an even smaller impact of 401(k) eligibility on wealth than do the wealth level regressions.

\section{$\underline{\text { V. Dilution }}$}

A crucial issue for interpreting these results and earlier results in the literature is whether and how average tastes for saving shifted over time for different groups. Note that this is an effort to estimate an unobserved variable that changes over time, and thus may prove difficult. In addition, the relevant comparison groups depend on the underlying specification. For regressions using samples of eligible families over time, such as the second test in table 4, the key issue is whether average tastes for saving among eligibles fell. For tests comparing samples of eligible and ineligible families, such as the third and fourth tests in table 4, the key issue is whether average tastes for saving fell over time for eligibles relative to ineligibles. For the tests conducted in this paper, the key issue is whether average tastes for saving fell over time for eligibles relative to ineligibles within earnings groups.

\section{A. Dilution Among Eligible Households Over Time}

Because of the rapid expansion of 401(k) eligibility in the 1980s, Bernheim (1997) argues that the sample of eligible households likely had declines in average taste for saving over time. He argues that the most committed savers were likely to be the first to be eligible for such plans, and over time an increasing 
number of less committed savers became eligible, reducing average tastes for saving among eligibles. This presents a prima facie case in favor of dilution among eligibles, but other factors need to be considered too.

For example, Ippolito (1993) posits that one reason 401(k) plans have become so popular is that they help firms attract good workers. Ippolito presents theory and evidence that workers with low discount rates (high tastes for saving) are likely to be more productive, but may be difficult to identify. A 401(k) plan helps solve this problem in several ways. First, by providing employer matching, the firm is able to pay workers who are willing to save more than those who are not. This will prove relatively more attractive to workers with high tastes for saving and thus will help attract and retain such workers. Second, workers with high discount rates (or low tastes for saving) will be able to access the cash in their account if they quit the firm. This will encourage such workers to leave. The Ippolito model suggests that over time, holding constant the pool of firms that offer $401(\mathrm{k}) \mathrm{s}$, the eligible sample should become less diluted--that is, that average tastes for saving should rise among eligibles. Of course, as Bernheim emphasizes, the pool of firms that offered 401(k)s expanded rapidly, which could cause dilution among eligibles over time. The net effect of these two factors is difficult to discern.

Some evidence can be obtained from the fact that 401(k) participation rates, conditional on eligibility and employer matching, rose over time. The opposite would be expected if the sample of eligibles were becoming diluted. Table 1 shows that participation rates, conditional on eligibility, in the SIPP have increased over time. But recall that participation is defined in the SIPP as having a positive balance, not actively making a contribution. So, even with dilution, this rate could rise over time.

More compelling evidence comes from the Current Population Survey (CPS) for 1988 to 1993. The CPS data are important because participation can be defined as making a contribution in the current period. Using this definition, one would not expect conditional participation rates to rise, if the sample of eligibles were becoming more diluted. But table 10 shows that among eligible workers, participation rates rose from 1988 to 1993 in all earnings groups, and by substantial amounts. 
Bernheim (1999) notes that participation may have increased because of the tightening of nondiscrimination rules in the late 1980 s, and that an effective way for employers to meet the tighter rules was to provide matching contributions. However, table 10 also shows that participation rates rose among employees who did not receive a matching contribution. In addition, if matching were being used to meet nondiscrimination rules, one would expect participation to rise more rapidly among low-earners than among high-earners. Table 10, however, shows that the increase in participation rates was higher for workers earning $\$ 30,000-\$ 75,000$ than for workers earning less than $\$ 30,000$. This difference is even larger among firms that matched. Adding controls for pension status, and thus changes in coverage over time, does not affect these findings. Alternatively, eligibles could be participating at a higher rate, but participants could be contributing less on average. In fact, however, table 11 shows that in almost all earnings and matching categories, participants contributed more in 1993 than in $1988 .^{21}$

\section{B. Dilution of Eligible Households Relative to Ineligible Households}

If average tastes for saving fell among eligibles, but fell by the same amount among ineligibles, then there would be no net bias from dilution issues. This could occur if the workers who became newly eligible for 401(k)s over time had higher than average tastes for saving among ineligibles, or if those who were eligible but became ineligible had lower than average tastes for saving among eligible workers.

Evidence on dilution of eligibles relative to ineligibles as a group can be gleaned from different sources. First, job-leavers tend to cash out their 401(k) balances and thus leave the pool of eligible workers (Burman, Coe and Gale 1999). Job-stayers tend to be savers. For example, Even and MacPherson (1999) find that workers who are more likely to participate in $401(\mathrm{k}) \mathrm{s}$ conditional on eligibility--that is, those with

\footnotetext{
${ }^{21}$ There are, of course, other possibilities for why participation rose even though the sample became more diluted, but none seems convincing. For example, employers could have responded in other ways than matching, such as financial education. But Bernheim and Garrett (1995) note that the big push in financial education did not even begin until the early 1990s and that it covered only a fraction of employers and employees by the early 1990s. In addition, 401(k) participation could have risen because the stock market became more popular during this period, but if that were the case, one would have expected IRA participation to rise, too, but it did not.
} 
higher tastes for saving--are also more likely to be "stayers" on the job--that is, to have long job tenure. These results suggest that over time, those with higher tastes for saving are attracted to $401(\mathrm{k}) \mathrm{s}$, while those with lower tastes tend to drop out of the pool of eligible workers.

Second, Pence (2000) provides data on self-reported motives for saving among eligible and ineligible households in the Survey of Consumer Finances from 1989 to 1995 . These results show a decline in propensities to save for eligibles relative to ineligibles for some saving categories and an increase in other saving categories. On balance, motives for saving do not appear to have changed very much for eligibles as a group compared to ineligibles over the sample period. This is consistent with no dilution having occurred for eligibles as a group relative to ineligibles as a group.

\section{Dilution of Eligibles Relative to Ineligibles within Earnings Groups}

The most important dilution issue for our purposes is whether average tastes for saving declined among eligibles relative to ineligibles within the same earnings classes. There is little evidence on which to base such a judgment. Table 3 does show that, within earnings classes, the relative values of age and education are very similar at a point in time for eligibles and ineligibles and do not change relative values over time. To the extent that tastes for saving are correlated with these factors, there is little evidence of any shift in tastes for saving between eligibles and ineligibles, controlling for earnings.

A more difficult hypothesis to judge is, loosely, that eligible workers have "good jobs," ineligible workers have "bad jobs" and that over the time period in question good jobs got better and bad jobs got worse. This possibility merits several comments, though. First, the regressions already control for earnings, age, education, and non-401(k) pension coverage. Second, regressions that control additionally for health insurance coverage and for industry and occupation generate similar results. Thus, in order to affect our results, any change in prospects for good and bad jobs would have to go beyond the change in prospects implied by all of these observable criteria. Third, a dominant feature of "bad jobs" is the lack of wage growth, but average age-earnings profiles look very similar for eligibles and ineligibles in the 1991 cross- 
section. These estimates do not follow individuals over time, but there is nevertheless no evidence that older ineligible workers are doing worse relative to younger ineligible workers than older eligible workers are doing compared to younger eligible workers. Finally, the impact of having a good job get better or a bad job get worse can change saving in different ways, depending on whether the change was anticipated, expected to be permanent and other factors. Thus, even if the job dichotomy view is correct, it is difficult to formulate unambiguous implications for saving.

\section{Evidence from IRA participation}

Bernheim (1999) argues that changes in the propensity to hold IRAs between 1987 and 1991 are a good indicator of the extent of dilution because IRA ownership is a stable indicator of tastes for saving during that period. Thus, to test for dilution, we estimate three separate probits. The first examines all eligible households in 1987 and 1991, with a right hand side specification the same as in (2). This shows a statistically significant decline in IRA participation among eligibles between 1987 and 1991 of about 5 percentage points, and under Bernheim's argument, is evidence of dilution of the eligible sample.

The second probit examines all households in 1987 and 1991 and uses a right hand side specification like (6), but allows for only one year-effect for eligibles and ineligibles (that is, it sets $\delta_{\mathrm{Ek}}=\delta_{\mathrm{E}}$ for all $\mathrm{k}$ and $\delta_{\mathrm{IK}}=\delta_{\mathrm{I}}$ for all $\mathrm{k}$ ). The result implies that eligibles as a group were only 1.8 percentage points less likely to hold an IRA in 1991 than 1987, compared to the change for ineligibles. Moreover, the effect is not significant $(t=1.3)$. This suggests that the case for dilution of eligibles relative to ineligibles is significantly weaker than the case for dilution of the overall sample of eligibles over time.

The third probit examines all households in 1987 and 1991 and uses a right hand side specification like (6), allowing the change in probability of IRA ownership to vary across time, earnings class, and eligibility status. None of the six estimated coefficients are significantly different from zero, and two are actually positive. This suggests that the case that there is dilution within earnings classes is even weaker than the case that there is dilution of eligibles relative to ineligibles. 


\section{Extensions}

\section{A. Sensitivity Analysis}

The models estimated above extend the existing literature in many ways, but can in turn be extended further. In this section, we discuss a variety of alternative specifications. All were carried out relative to the basic specification in table 7 . The first was to measure the effect of 401(k) eligibility on wealth measures less 401(k) wealth rather than on wealth less saving incentive balances. This hardly changed the results at all. The second was to approximate employer matching contributions, which really should be considered as part of wages, by raising the earnings of all participants by 5 percent. This also had virtually no effect on the outcomes, in part because wages were raised for participants in both 1987 and 1991, so the difference over time tended to wash out. Estimates using the 25 th and 75 th percentiles rather than the medians were consistent with the results in the paper, but had low levels of significance.

Somewhat surprisingly, four additional and rather disparate alternative specifications all had a common effect. The four specifications were as follows. (a) Limit the top earnings group to those who earned less than $\$ 110,000$, in case outliers were driving the results for this group; (b) Restrict the sample to households that were aged 25-59 rather than 25-64 in each sample year, to reduce any problems with early retirement and because this age group faces early withdrawal penalties; (c) Restrict the sample to households that were aged 25-59 in 1987 and 29-64 in 1991, in order to follow the same age cohorts over time. This regression controlled for age-in-1987 rather than current age. (d) Add the self-employed into the sample, to account for possible differences in shifting employment patterns between eligibles and ineligibles over time. The common effect was to make the coefficient on the highest earnings group in the financial assets equation positive, large and significant (about the same size as the coefficient for the $\$ 50,000-\$ 75,000$ indicator in the first row of table 7). None of the coefficients in the other equations changed significantly, however, so the overall conclusions remain the same.

We also considered expanding the sample to include SIPP data from either 1984 or 1993. However, 
the 1984 data lack information on 401(k) balances. This would permit estimates of non-401(k) wealth measures, as in Poterba, Venti and Wise (1995) and Engen and Gale (1997), but such estimates cannot be conclusive. The absence of a significant negative coefficient on the eligibility term would not prove that 401(k)s do not raise saving, and the presence of a significant negative coefficient would not demonstrate much in the way of substitution. Tables 6 and 7 above demonstrate these facts for the 1987-91 period. In the 1993 SIPP, the 401(k) participation rate, conditional on eligibility, is lower than in 1991. However, other data sources including the Surveys of Consumer Finances, the Form 5500s and the Current Population Surveys suggest the conditional participation rate should have increased.

\section{B. Biases}

At least two items may bias our results toward overstating the effects of 401(k) plans on private saving. First, there is some evidence that firms in the 1980s used 401(k) plans as pension replacements on the margin (see Gale, Papke, and VanDerhei 2000). That is, firms stopped improving or "froze" their defined benefit pension plans and poured marginal pension resources into $401(\mathrm{k})$ plans instead. To the extent that this occurred, 401(k) eligible households would have incurred a reduction in wealth, but one that is not observable in the SIPP, because the SIPP does not have information on the value of accumulated (non401(k)) pension rights among working households. ${ }^{22}$

Second, table 2 shows that about 70 percent of $401(\mathrm{k})$ balances in the SIPP are held by families with earnings above $\$ 40,000$ and our results suggest that these balances do not represent new private saving. However, recall that wealthy households are under represented in the SIPP. We extracted a sample from the 1995 Survey of Consumer Finances, consisting of employed households, with no one self-employed, and where the head was between the ages of 25 and 64 . In that sample, 80 percent of $401(\mathrm{k})$ balances were held by households with earnings above $\$ 50,000$ (in 1991 dollars) and 89 percent were held by households with

\footnotetext{
${ }^{22}$ It is also possible that firms dropped their defined benefit plans altogether and replaced them with 401(k)s. See Papke (1999). In the SIPP data, however, non-401(k) pension coverage rates did not change significantly for eligibles relative to ineligibles over the sample period.
} 
earnings above $\$ 40,000$. If the SIPP understates the proportion of $401(\mathrm{k})$ balances held by higher-earning households, our results may overstate the impact of $401(\mathrm{k}) \mathrm{s}$ on private saving.

\section{Conclusion}

The impact of 401(k) plans on household wealth is a crucial issue for both academic analysis of the determinants of saving and public policy discussions concerning retirement income. This paper addresses conceptual and econometric problems that have arisen in previous work on $401(\mathrm{k}) \mathrm{s}$ and wealth and provides

new estimates. We make two principal adjustments in our model relative to the previous literature. The first is to allow the effects of $401(\mathrm{k}) \mathrm{s}$ to vary by earnings class over time. The second is to estimate using a variety of functional forms for the dependent variable that are more consistent with theory, are robust to differences in initial asset position, and are robust to economy-wide effects that raise or lower all asset values proportionately, or have different effects across earnings classes.

Several different tests suggest that the impact of $401(\mathrm{k})$ eligibility over time varies significantly by earnings class; that during the sample period at least two-thirds of 401(k) balances accrue to households in groups where 401(k) eligibility is not associated with higher wealth for eligibles relative to ineligibles; and that it is the households that have low earnings or low wealth for whom 401(k)s may tend to be net saving. The results for low earners, however, are generally much less significant when using the bootstrap standard errors. Our estimates are robust, however, across different functional forms for the dependent variable. In addition, the same general results emerge when estimating on the sample as a whole as when estimating on various sub-groups and aggregating to obtain the overall estimate.

If we rely on our estimated analytical standard errors, then our estimates on the overall proportion of 401(k)s that represent net private saving are substantially below those of Poterba, Venti and Wise (1995), who find no reduction in other private wealth due to $401(\mathrm{k}) \mathrm{s}$. If we rely on bootstrap standard errors, then our results are not much larger than our earlier estimates in Engen and Gale (1997). Note that all of these 
results overstate the effects of $401(\mathrm{k})$ eligibility on national saving, because they do not account for the attendant loss of revenue.

Our findings are also similar to some of the results in Benjamin (2000). Benjamin uses propensity score methods to control for tastes for saving and finds that, among homeowners and households with IRAs, there is no effect of $401(\mathrm{k}) \mathrm{s}$ on national saving, but positive effects of $401(\mathrm{k})$ eligibility among renters and households without IRAs. Aggregating these estimates would suggest small overall impact of 401(k)s, but his estimates using the overall sample show a somewhat larger positive effect.

The empirical finding that saving incentives may be more likely to raise saving for low earners or low savers is consistent with a variety of other results in the literature. Gale and Scholz (1994) find similar results for IRAs, and Gale (1998) finds similar results for employer-provided pensions. In addition, the mechanism whereby saving incentives might have positive effects on private saving for lower-earning or lower-saving households but not for higher earners is worth exploring. One possibility is that low-income households do not hold much in the way of stocks (Carney and Gale 1999, Poterba and Samwick 1999). This is not terribly surprising given the information and transactions costs, but it may be that $401(\mathrm{k}) \mathrm{s}$ raise saving for this group by providing cheap access to the stock market. Another possibility, exemplified by models developed in Samwick (1995) and others is tax-preferred, but illiquid retirement saving is a poor substitute for other saving for households with little wealth who need the saving for precautionary reasons. If so, then to the extent that low earning households do contribute to such plans, the contributions are more likely to be new saving. A third possibility is simply that higher earners or high-saving households are simply more economically sophisticated and hence have both the resources and the wherewithal to take advantage of sheltering strategies that allow them to capture the tax benefits of $401(\mathrm{k}) \mathrm{s}$ without sacrificing living standards.

Finally, as we have emphasized in earlier papers (Engen and Gale 1995, 1997), our findings point toward potentially important links between housing equity and financial assets in determining the adequacy of 
saving for retirement. This result is consistent with findings in Poterba and Samwick (1997, page 25), who conclude that debt and borrowing behavior are important factors in understanding financial preparation for retirement, and these links deserve further scrutiny on the part of economists. 


\section{$\underline{\text { References }}$}

Benjamin, Daniel J. 2000. "Does 401(k) Eligibility Increase National Savings?” Mimeo., London School of Economics.

Bernheim, B. Douglas. 1997. "Rethinking Saving Incentives." In Alan Auerbach, ed., Fiscal Policy: Lessons from Economic Research, MIT Press, forthcoming.

Bernheim, B. Douglas. 1999. “Taxation and Saving.” NBER Working Paper No. 7061 (March).

Bernheim, B. Douglas and Daniel M. Garrett. 1995. "The Determinants and Consequences of Financial Education in the Workplace: Evidence from a Survey of Households.” Mimeo., Stanford University (August).

Bloomfield, P. and W. Steiger, Least Absolute Deviations: Theory, Applications, and Algorithms. Boston: Birkhouser, 1983.

Burman, Leonard E., Norma B. Coe, and William G. Gale. 1999. "What Happens When You Show Them the Money?: Lump Sum Distributions, Retirement Income Security, and Public Policy.” Mimeo., Brookings Institution.

Carney, Stacie and William G. Gale. 1999. "Asset Accumulation in Low-Income Households," in Thomas M. Shapiro and Edward Wolff, Eds., Benefits and Mechanisms for Spreading Asset Ownership in the United

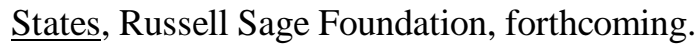

Curtin, Richard T., F. Thomas Juster, and James N. Morgan. 1989. "Survey Estimates of Wealth: An Assessment of Quality," in Robert E. Lipsey and Helen Stone Tice, eds., The Measurement of Saving, Investment, and Wealth, Chicago: University of Chicago Press: 473-551.

Dynan, Karen E., Jonathan Skinner, and Stephen P. Zeldes. 2000. "Do the Rich Save More?" Mimeo., Federal Reserve Board, April 6.

Engelhardt, Gary. 1999. "Have 401(k)s Raised Household Saving? Evidence from the Health and Retirement Study." Mimeo. (October).

Engen, Eric M., and William G. Gale. 1995. "Debt, Taxes and the Effects of 401(k) Plans on Household Wealth Accumulation.” Mimeo. (October).

Engen, Eric M., and William G. Gale. 1997. "Debt, Taxes and the Effects of 401(k) Plans on Household Wealth Accumulation.” Mimeo. (May).

Engen, Eric M., William G. Gale, and John Karl Scholz. 1996a. "The Illusory Effect of Saving Incentives on Saving." Journal of Economic Perspectives 10(4): 113-38.

Engen, Eric M., William G. Gale, and John Karl Scholz. 1996b. "The Effects of Tax-Based Saving Incentives on Saving and Wealth.” NBER Working Paper No. 5759 (September).

Engen, Eric M., William G. Gale, and Cori Uccello. 1999. “The Adequacy of Household Saving.” Brookings 
Papers on Economic Activity 2: 65-187.

Even, William E., and David A. MacPherson. 1999. “Employee Participation in 401(k) Plans.” Mimeo.

Feldstein, Martin S. 1980. "Inflation, Portfolio Choice, and the Prices of Land and Corporate Stock." American Journal of Agricultural Economics, 62(5): 910-16 (December).

Gale, William G. 1998. "The Effects of Pensions on Wealth: A Re-examination of Theory and Evidence," Journal of Political Economy, 106:4, 706-23 (August).

Gale, William G., Leslie E. Papke, and Jack VanDerhei. 2000. "The Shifting Structure of Private Pensions: Evidence, Causes and Consequences," in William G. Gale, John B. Shoven, and Mark J. Warshawsky, eds., The Evolving Pension System: Trends, Effects, and Proposals for Reform, Brookings, forthcoming.

Gale, William G., and John Sabelhaus. 1999. "Perspectives on the Household Saving Rate.” Brookings Papers on Economic Activity 1: 181-214.

Gale, William G., and John Karl Scholz. 1994. "IRAs and Household Saving." American Economic Review, 84:5, 1233-1260 (December).

Hubbard, R. Glenn, and Jonathan S. Skinner. 1996. “Assessing the Effectiveness of Saving Incentives.” Journal of Economic Perspectives 10(4): 73-90.

Hubbard, R. Glenn, Jonathan Skinner, and Stephen P. Zeldes. 1995. "Precautionary Saving and Social Insurance.” Journal of Political Economy 103(2): 360-99.

Ippolito, Richard A. 1993. "Selecting and Retaining High-Quality Workers: A Theory of 401(k) Pensions." Unpublished paper. Pension Benefit Guaranty Corporation, Washington (April).

Johnson, William, Yuichi Kitamura, and Derek Neal. 2000. "Evaluating a Simple Method for Estimating Black-White Gaps in Median Wages.” American Economic Review 90(2): 339-243 (May).

Kusko, Andrea, James M. Poterba, and David W. Wilcox. 1994. "Employee Decisions With Respect to 401(k) Plans: Evidence from Individual Level Data.” NBER Working Paper No. 4635 (February).

Laibson, David I., Andrea Repetto, and Jeremy Tobacman. 1998. "Self-Control and Saving for Retirement." Brookings Papers on Economic Activity 1: 91-172.

Madrian, Brigitte C. and Dennis F. Shea. 2000. "The Power of Suggestion: Inertia in 401(k) Participation and Savings Behavior.” NBER Working Paper No. 7682, May.

Maki, Dean M. 1999. “Household Debt and the Tax Reform Act of 1986.” Mimeo. (June).

Papke, Leslie E. 1999. “Are 401(k) Plans Replacing Other Employer-Provided Pensions? Evidence from Panel Data." Journal of Human Resources 34(2): 346-68.

Pence, Karen M. 2000. “401(k)s and Household Saving: New Evidence from the Survey of Consumer Finances.” Mimeo. (March). 
Poterba, James M. 1984. "Tax Subsidies to Owner-Occupied Housing: An Asset-Market Approach." Quarterly Journal of Economics 99(4): 729-52 (November).

Poterba, James M. and Andrew A. Samwick. 1997. "Household Portfolio Allocation Over the Life Cycle." NBER Working Paper No. 6185 (September).

Poterba, James M. and Andrew A. Samwick. 1999. "Taxation and Household Portfolio Composition: U.S. Evidence from the 1980s and 1990s.” Mimeo (October).

Poterba, James M., Steven F. Venti, and David A. Wise. 1995. "Do 401(k) Contributions Crowd Out Other Personal Saving?" Journal of Public Economics 58: 1-32.

Poterba, James M., Steven F. Venti, and David A. Wise. 1996a. "How Retirement Programs Increase Savings." Journal of Economic Perspectives 10(4): 91-112.

Poterba, James M., Steven F. Venti, and David A. Wise. 1996b. "Personal Retirement Saving Programs and Asset Accumulation: Reconciling the Evidence.” NBER Working Paper No. 5599 (May).

Sabelhaus, John, and Ken Ayotte. 1998. "The Effect of Tax-Deferred Saving Plans on Household Wealth Accumulation: Evidence from the Survey of Consumer Finances.” Mimeo. (March).

Samwick, Andrew A. 1995. "The Limited Offset Between Pension Wealth and Other Private Wealth: Implications of Buffer-Stock Saving.” Mimeo. (December).

Stiglitz, Joseph E. 1988. Economics of the Public Sector, second edition, New York: W.W. Norton and Company.

Summers, Lawrence H. 1981. "Inflation, the Stock Market, and Owner-Occupied Housing." American Economic Review 71(2): 429-434 (May).

Rogers, William. 1992. “Quantile Regression Standard Errors.” Stata Technical Bulletin (Sept.): 16-9.

United States Department of Labor. Pension and Welfare Benefits Administration. 1999. Private Pension Plan Bulletin, Abstract of 1995 Form 5500 Annual Reports. No. 2 (Summer). 


\section{Table 1}

\section{1(k) Participation and Eligibility Rates, by Family Earnings Category, 1984-91*}

\begin{tabular}{|c|c|c|c|c|c|c|c|c|}
\hline & \multicolumn{8}{|c|}{ Earnings Category } \\
\hline & $\begin{array}{r}0- \\
10,000 \\
\end{array}$ & $\begin{array}{r}10,000- \\
20,000 \\
\end{array}$ & $\begin{array}{r}20,000- \\
30,000 \\
\end{array}$ & $\begin{array}{r}30,000- \\
40,000 \\
\end{array}$ & $\begin{array}{r}40,000- \\
50,000 \\
\end{array}$ & $\begin{array}{r}50,000- \\
75,000 \\
\end{array}$ & $75,000+$ & All \\
\hline \multicolumn{9}{|l|}{1984} \\
\hline \% Eligible & 3.6 & 7.0 & 11.5 & 15.4 & 19.5 & 26.0 & 37.1 & 14.7 \\
\hline \% Participating & 2.0 & 3.3 & 6.1 & 8.2 & 10.0 & 17.2 & 28.1 & 8.5 \\
\hline Participants/Eligibles (\%) & 56.6 & 46.6 & 53.2 & 53.1 & 51.2 & 65.9 & 75.6 & 57.7 \\
\hline \multicolumn{9}{|l|}{1987} \\
\hline \% Eligible & 4.1 & 9.8 & 16.1 & 23.9 & 30.0 & 38.8 & 45.5 & 21.9 \\
\hline \% Participating & 2.1 & 5.6 & 8.6 & 14.0 & 18.3 & 25.9 & 36.5 & 13.7 \\
\hline Participants/Eligibles (\%) & 51.2 & 56.6 & 53.3 & 58.5 & 61.0 & 66.7 & 80.1 & 62.6 \\
\hline \multicolumn{9}{|l|}{1991} \\
\hline \% Eligible & 8.1 & 20.9 & 33.6 & 45.2 & 49.5 & 60.6 & 60.4 & 37.8 \\
\hline \% Participating & 5.5 & 13.9 & 20.9 & 31.0 & 37.2 & 44.4 & 50.9 & 26.7 \\
\hline Participants/Eligibles (\%) & 68.0 & 66.4 & 62.2 & 68.6 & 75.2 & 73.4 & 84.4 & 70.7 \\
\hline
\end{tabular}

* All figures are weighted. Family earnings categories are given in 1991 dollars. A household is defined as participating in a $401(\mathrm{k})$ if the household has a positive $401(\mathrm{k})$ balance.

Source: Author's calculations from the SIPP. 
Table 2

\section{Allocation of Eligibles, Participants, 401(k) Balances, and Saving Incentive Balances, by Earnings Category *}

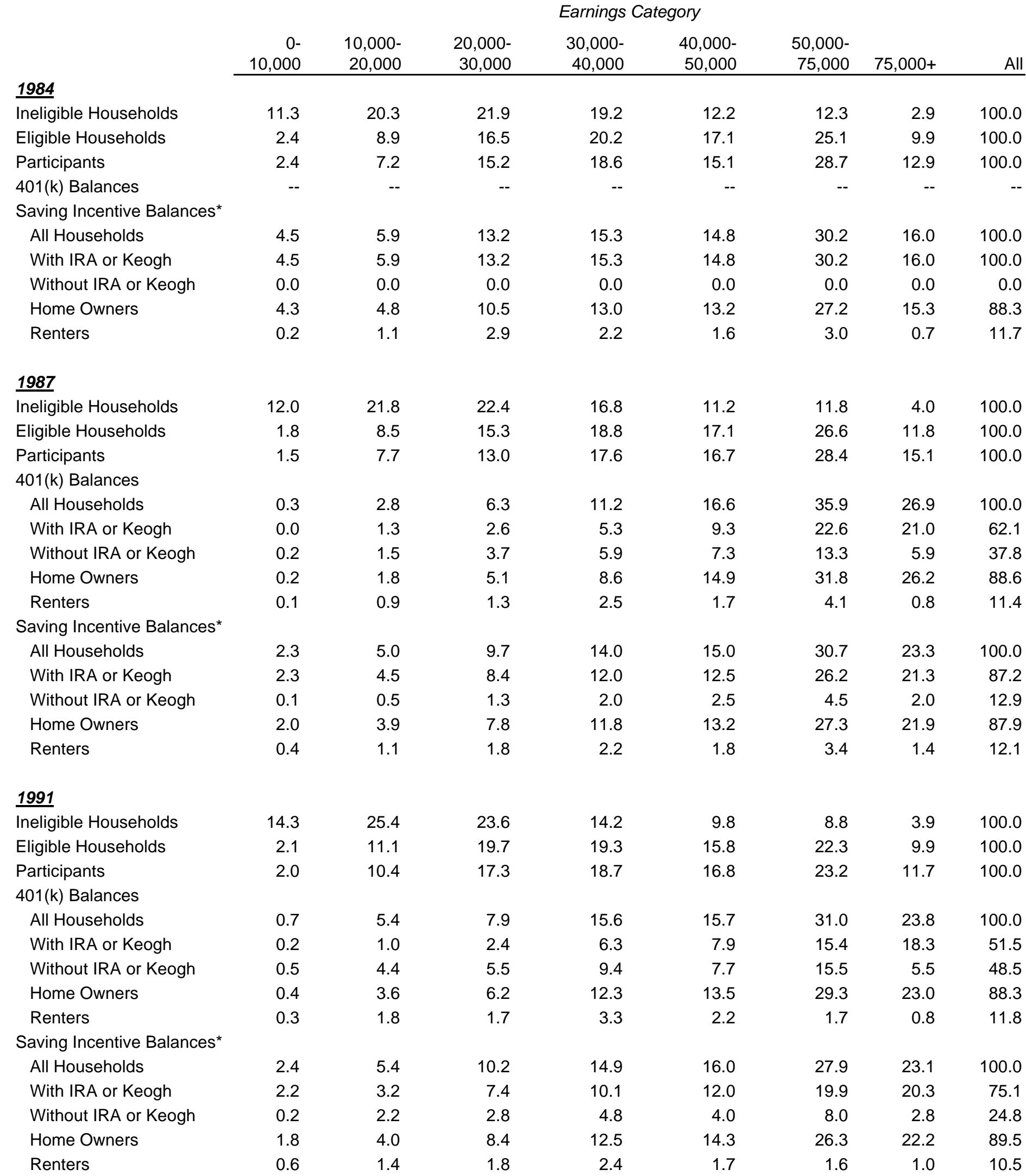

* Saving incentive balances are the sum of $401(\mathrm{k}) \mathrm{s}$, IRAs, and Keoghs. Values for 1984 omit $401(\mathrm{k}) \mathrm{s}$. Family Earnings categories are given in 1991 dollars.

Source: Authors' calculations from the SIPP. 
Table 3

Characteristics of the Sample, by 401(k) Eligibility and Earnings Category, 1984-91*

\begin{tabular}{|c|c|c|c|c|c|c|c|c|}
\hline Family Earnings Category & $\begin{array}{r}0- \\
10,000 \\
\end{array}$ & $\begin{array}{r}10,000- \\
20,000 \\
\end{array}$ & $\begin{array}{r}20,000- \\
30,000 \\
\end{array}$ & $\begin{array}{r}30,000- \\
40,000 \\
\end{array}$ & $\begin{array}{r}40,000- \\
50,000 \\
\end{array}$ & $\begin{array}{r}50,000- \\
75,000 \\
\end{array}$ & $75,000+$ & All \\
\hline \multicolumn{9}{|l|}{1984} \\
\hline \multicolumn{9}{|l|}{ Ineligible Families } \\
\hline Family Earnings & 5,559 & 15,317 & 24,809 & 34,715 & 44,734 & 59,641 & 99,113 & 31,457 \\
\hline Education level of head of household & 11.4 & 11.8 & 12.4 & 13 & 13.3 & 14.2 & 15.5 & 12.7 \\
\hline Age of head of household & 43.5 & 40.2 & 39.6 & 40.2 & 41 & 41.7 & 43.4 & 40.8 \\
\hline Percent Married & 31.3 & 43.3 & 59.9 & 77.3 & 87.8 & 91.1 & 93.3 & 64.8 \\
\hline Percent own home & 45.9 & 46.5 & 57.8 & 69.5 & 77.6 & 84.9 & 88.4 & 63.0 \\
\hline Percent with IRA or Keogh & 11.2 & 10.2 & 16.6 & 23.4 & 28.9 & 41.6 & 63.3 & 21.9 \\
\hline $\mathrm{n}=$ & 897 & 1,618 & 1,699 & 1,505 & 972 & 988 & 240 & 7,919 \\
\hline \multicolumn{9}{|l|}{ Eligible Families } \\
\hline Family Earnings & 6,687 & 15,935 & 25,196 & 34,942 & 44,716 & 60,585 & 95,136 & 45,010 \\
\hline Education & 12.2 & 12.1 & 12.6 & 13.5 & 13.9 & 14.7 & 16.1 & 13.8 \\
\hline Age & 43.3 & 43.4 & 42.1 & 39.9 & 40.8 & 41.7 & 45.8 & 41.8 \\
\hline Percent Married & 42.9 & 43.5 & 58.6 & 69.6 & 84.0 & 91.6 & 95.7 & 75.4 \\
\hline Percent own home & 59.9 & 60.5 & 61.2 & 72.6 & 85.5 & 87.0 & 94.1 & 77.3 \\
\hline Percent with IRA or Keogh & 16.4 & 14.6 & 22.2 & 21.2 & 30.8 & 46.8 & 66.0 & 33.2 \\
\hline $\mathrm{n}=$ & 35 & 127 & 231 & 274 & 236 & 345 & 143 & 1,391 \\
\hline
\end{tabular}

1987

Ineligible Families

Family Earnings

Education level of head of household

15,245

24,811

34,609

44,630

60,10

98,584

31,348

$11.1 \quad 11.8$

13.4

14.3

15.5

12.7

39.2

39.9

40.5

Percent Married

42.3

39.1

58.0

84.3

52.6

74.8

41

43.6

40.6

Percent own home

44.1

67.7

89.7

91.0

63.1

10.9

11.0

77.4

81.5

86.4

59.8

17.6

25.6
1,402

31.1

43.6

59.6

22.9

$\mathrm{n}=$

Eligible Families

Family Earnings

Education

$5,845 \quad 15,992$

25,187

35,019

44,751

60,28

337

8,297

Age

12.2

13.7

14.1

40.6

40.2

40.4

45.2

62.0

79.0

Percent own home

Percent with IRA or Keogh

36.6

59.5

69.1

79.2

16.2

32.9

37.2

352

451

406

97,904

47,194

$14.6 \quad 15.5$

13.9

42.4

43.8

41.5

90.0

95.6

71.2

85.8

92.1

74.5

49.6

71.6

39.0

$\mathrm{n}=$

44

191

639

1991

Ineligible Families

Family Earnings

Education level of head of household

15,084

24,785

34,533

44,440

59,737

14.7

93,835

28,706

11.5

12.8

13.9

39.7

36.0

39.8

56.9

80.5

72.6

30.5

10.5

41.0

54.3

72.3

41

88.6

15.9

12.9

Percent own home

43.4
10.0

67.0

79.1

43.8

40.7

Percent with IRA or Keogh

971

1,672

1,478

902

38.9

90.4

58.5

57.1

Eligible Families

Family Earnings

6,385

Education

15,561
11.9
41.3
37.8
53.9
11.0
426
25,366
50.0
63.0

35,135

44,706

60,446

$13.5 \quad 13.9$

41.9

80.9

80.7

38.0

70.6

596

84.8

20.3

6,448

Percent Married

41.1

27.0

574

247

43,561

$14.5 \quad 15.7$

13.7

41.7

42.7

41.4

87.6

94.5

68.8

90.1

92.3

74.8

15.8
79

734

41.7

66.0

32.1

3,818

* Other than sample size, the values represent weighted means. All dollar figures are in 1991 dollars.

Source: Authors' calculations from the SIPP. 


\section{Table 4}

\section{Summary of Previous Research Methodologies}

Section

of Paper

II (A)

$\begin{array}{cc}\text { PVW } & \text { Cross- } \\ \text { (1995) } & \text { Section }\end{array}$

II (B)

$\begin{array}{lc}\text { PVW } & \text { Like } \\ \text { (1995) } & \text { Families }\end{array}$

$E$ in

1984,1987 and 1991

$\begin{array}{lcc}\text { II (B) } 2 & \text { PVW } & \text { Like } \\ & \text { (1995) } & \text { Families }\end{array}$

$E$ and $I$ in
1984,1987 ,
and 1991

II (B) 3

$E G$
$(1997)$

\section{$E$ and $I$ in}

Dependent

$\underline{\text { Variable }^{* *}}$

NFA

NFA-SI

1) Test compares the wrong measure of assets and assumes all $401(\mathrm{k}) \mathrm{s}$ are new saving

(2) Test focuses on narrow measure of net worth.

NFA

(1) Possible dilution of eligible households over time.

(2) No control group.

(3) The identifying assumption that nothing else besides $401(\mathrm{k}) \mathrm{s}$ affected NFA over time is implausible.

(4) Requires 401(k)s to have the same additive effects across earnings classes.

(5) Test focuses on narrow measure of wealth.

NFA (1) Possible dilution of eligibles relative to ineligibles over time.

NFA-SI (2) Control group is ineligible households as a goup.

(3) The identifying assumption that nothing else besides $401(\mathrm{k}) \mathrm{s}$ affected NFA for eligibles relative to ineligibles over time is implausible.

(4) Requires 401(k)s to have the same additive effects across earnings classes.

(5) Test focuses on narrow measure of wealth. 1987,1991
W

W-SI
(1) Possible dilution of eligibles relative to ineligibles over time.

(2) Control group is ineligible households as a group.

(3) The identifying assumption that nothing else besides $401(\mathrm{k}) \mathrm{s}$ affected $\mathrm{W}$ for eligibles relative to ineligibles over time is implausible.

(4) Requires $401(\mathrm{k}) \mathrm{s}$ to have the same additive effects across earnings classes. 


\section{Table 5}

\section{Change in Real Median Wealth Measures for Eligible Households Relative to Ineligible Households, By Earnings Category, 1987-91*}

\begin{tabular}{|c|c|c|c|c|c|c|c|}
\hline \multirow[b]{2}{*}{ Wealth Measure } & \multirow[b]{2}{*}{$\begin{array}{r}10,000- \\
20,000 \\
\end{array}$} & \multicolumn{6}{|c|}{ Earnings Category } \\
\hline & & $\begin{array}{r}20,000- \\
30,000 \\
\end{array}$ & $\begin{array}{r}30,000- \\
40,000 \\
\end{array}$ & $\begin{array}{r}40,000- \\
50,000 \\
\end{array}$ & $\begin{array}{r}50,000- \\
75,000 \\
\end{array}$ & $75,000_{+}$ & All \\
\hline 401(k) Balances & 421 & 342 & 1,697 & 2,035 & 2,587 & 5,927 & 1,214 \\
\hline Saving Incentive Balances & 618 & 476 & 1,587 & 3,139 & 2,279 & 7,501 & 981 \\
\hline Net Financial Assets & 543 & -441 & 3,042 & 2,723 & 2,162 & $-1,762$ & 481 \\
\hline $\begin{array}{l}\text { Net Financial Assets - } \\
\text { Saving Incentive Balances }\end{array}$ & 0 & -371 & 259 & $-1,210$ & -883 & $-12,859$ & -847 \\
\hline Housing Equity & 800 & $-3,651$ & 2,618 & 4,381 & $-6,270$ & $-10,684$ & $-4,716$ \\
\hline House Value & 7,700 & $-12,129$ & 3,794 & 8,000 & $-1,032$ & 19,968 & 6,057 \\
\hline Mortgage Debt & 0 & 0 & 3,311 & 10,206 & 8,794 & 22,297 & 9,903 \\
\hline Wealth & 4,160 & 1,170 & 5,684 & 5,074 & 1,478 & $-3,518$ & $-3,682$ \\
\hline $\begin{array}{l}\text { Wealth - Saving Incentive } \\
\text { Balances }\end{array}$ & 2,652 & -444 & 2,097 & 203 & $-2,684$ & $-18,751$ & $-6,749$ \\
\hline
\end{tabular}


Table 6

Effects of 401(k) Eligibility on Household Wealth, 1987-91: Replications and Extensions

\begin{tabular}{|c|c|c|c|c|c|c|c|c|}
\hline \multirow[b]{2}{*}{ Sample } & \multirow[b]{2}{*}{ Dependent Variable } & \multirow[b]{2}{*}{$\begin{array}{c}\text { Coefficient on } \\
\text { IN91 }\end{array}$} & \multicolumn{6}{|c|}{ Coefficient on IN91 ${ }^{\star}$ Earnings Category } \\
\hline & & & $\begin{array}{r}10,000- \\
20,000\end{array}$ & $\begin{array}{r}20,000- \\
30,000\end{array}$ & $\begin{array}{r}30,000- \\
40,000 \\
\end{array}$ & $\begin{array}{r}40,000- \\
50,000\end{array}$ & $\begin{array}{r}50,000- \\
75,000 \\
\end{array}$ & $75,000+$ \\
\hline \multicolumn{9}{|l|}{$\overline{\text { Eligibles }}$} \\
\hline & Net Financial Assets & 1,190 & 1,003 & 327 & 1,182 & 1,466 & 3,458 & 7,756 \\
\hline & & $(2.91)$ & $(0.77)$ & $(0.34)$ & $(1.31)$ & $(1.51)$ & $(4.40)$ & (6.63) \\
\hline & & {$[2.57]$} & [1.62] & {$[0.49]$} & [1.42] & {$[1.15]$} & {$[1.70]$} & {$[1.41]$} \\
\hline & Net Financial Assets - Saving & & & & & & & \\
\hline & Incentive balances & -600 & -67 & -318 & -443 & $-1,003$ & $-1,816$ & $-3,138$ \\
\hline & & $(3.41)$ & $(0.10)$ & $(0.64)$ & $(0.97)$ & $(2.03)$ & $(4.54)$ & $(5.27)$ \\
\hline & & {$[2.80]$} & {$[0.25]$} & {$[0.95]$} & {$[1.27]$} & {$[1.75]$} & {$[1.50]$} & {$[0.97]$} \\
\hline \multicolumn{9}{|c|}{ Ineligibles } \\
\hline & Net Financial Assets & -51 & 24.0 & -88.0 & -278.0 & 255.0 & -912.0 & 7223.0 \\
\hline & & $(0.79)$ & $(0.21)$ & $(0.75)$ & $(1.93)$ & $(1.45)$ & $(5.18)$ & $(25.64)$ \\
\hline & & {$[0.75]$} & {$[0.25]$} & {$[0.88]$} & [1.29] & {$[0.50]$} & [0.73] & [1.46] \\
\hline & Net Financial Assets - Saving & & & & & & & \\
\hline & Incentive balances & -53 & 0 & -59 & -217 & -139 & -543 & 1,693 \\
\hline & & $(1.20)$ & $(0)$ & $(0.58)$ & $(1.76)$ & $(0.92)$ & (3.59) & $(7.00)$ \\
\hline & & {$[1.26]$} & {$[0]$} & {$[0.78]$} & {$[1.37]$} & {$[0.34]$} & {$[0.86]$} & {$[0.43]$} \\
\hline \multicolumn{9}{|c|}{ Differences } \\
\hline & Net Financial Assets & 1,241 & 979 & 415 & 1,460 & 1,211 & 4,370 & 533 \\
\hline & & $(3.00)$ & $(0.75)$ & $(0.43)$ & $(1.60)$ & $(1.23)$ & $(5.43)$ & $(0.44)$ \\
\hline & & [2.65] & {$[1.56]$} & {$[0.61]$} & {$[1.70]$} & {$[0.88]$} & [1.83] & {$[0.07]$} \\
\hline & Net Financial Assets - Saving & & & & & & & \\
\hline & Incentive balances & -547 & -67 & -259 & -226 & -864 & $-1,273$ & $-4,831$ \\
\hline & & (3.01) & $(0.10)$ & $(0.51)$ & $(0.48)$ & (1.67) & $(2.98)$ & (7.52) \\
\hline & & [2.50] & {$[0.25]$} & {$[0.75]$} & [0.59] & [1.23] & [0.93] & {$[0.95]$} \\
\hline
\end{tabular}

*The table reports the results of estimating equations (2) and (4) for eligible households, and equations (3) and (5) for ineligible households.

The values in parentheses represent the absolute value of t-statistics using analytical standard errors; the values in square brackets

represent the absolute value of $t$-statistics using bootstrapped standard errors with 200 iterations. Family earnings categories are given

in 1991 dollars.

Source: Authors' calculations from the SIPP. 
Table 7

Effects of 401(k) Eligibility on Household Wealth Levels, by Earnings Category, 1987-91*

\begin{tabular}{|c|c|c|c|c|c|c|}
\hline \multirow[b]{2}{*}{ Dependent Variable } & \multicolumn{6}{|c|}{ Coefficient on ELIG*IN91*Earnings Category } \\
\hline & $\begin{array}{r}10,000- \\
20,000 \\
\end{array}$ & $\begin{array}{r}20,000- \\
30,000 \\
\end{array}$ & $\begin{array}{r}30,000- \\
40,000 \\
\end{array}$ & $\begin{array}{r}40,000- \\
50,000 \\
\end{array}$ & $\begin{array}{r}50,000- \\
75,000 \\
\end{array}$ & $75,000+$ \\
\hline \multirow[t]{3}{*}{ Net Financial Assets } & 512 & 333 & 998 & 1,965 & 4,079 & 572 \\
\hline & $(1.00)$ & $(0.82)$ & $(2.47)$ & $(4.32)$ & $(10.05)$ & $(0.91)$ \\
\hline & {$[0.70]$} & {$[0.41]$} & {$[0.97]$} & {$[1.27]$} & {$[1.71]$} & {$[0.08]$} \\
\hline \multicolumn{7}{|l|}{ Net Financial Assets - } \\
\hline \multirow[t]{3}{*}{ Saving Incentive Balances } & 121 & -289 & -33 & -963 & $-1,216$ & $-5,182$ \\
\hline & $(0.37)$ & $(1.13)$ & $(0.13)$ & $(3.34)$ & $(4.73)$ & $(13.03)$ \\
\hline & {$[0.34]$} & {$[0.80]$} & {$[0.07]$} & {$[1.56]$} & {$[0.99]$} & [1.00] \\
\hline \multirow[t]{3}{*}{ Wealth } & 1,706 & 301 & 3,976 & $-1,574$ & 344 & $-5,520$ \\
\hline & $(0.74)$ & $(0.17)$ & $(2.18)$ & $(0.77)$ & $(0.19)$ & $(1.95)$ \\
\hline & {$[0.64]$} & {$[0.15]$} & {$[0.92]$} & {$[0.32]$} & {$[0.06]$} & {$[0.35]$} \\
\hline \multicolumn{7}{|l|}{ Wealth - Saving Incentive } \\
\hline \multirow[t]{3}{*}{ Balances } & -246 & $-1,888$ & 2,602 & $-3,844$ & $-5,496$ & $-21,242$ \\
\hline & $(0.11)$ & $(1.06)$ & $(1.46)$ & $(1.91)$ & $(3.06)$ & $(7.65)$ \\
\hline & {$[0.13]$} & {$[0.77]$} & {$[0.86]$} & {$[0.66]$} & {$[1.21]$} & {$[1.58]$} \\
\hline
\end{tabular}

\footnotetext{
* The table reports the results of estimating equation (6). The values in parentheses represent the absolute value of $t$-statistics using analytical standard errors; the values in square brackets represent the absolute value of t-statistics using bootstrapped standard errors with 200 iterations. Family earnings categories are given in 1991 dollars.

Source: Authors' calculations from the SIPP.
} 
Table 8

Effects of 401(k) Eligibility on Household Wealth Levels, by Saver Group and Earnings Category, 1987-91*

\begin{tabular}{|c|c|c|c|c|c|c|c|}
\hline \multirow[b]{2}{*}{$\underline{\text { Sample }}$} & \multirow[b]{2}{*}{ Dependent Variable } & \multicolumn{6}{|c|}{ Coefficient on ELIG*IN91*Earnings Category } \\
\hline & & $\begin{array}{r}10,000- \\
20,000 \\
\end{array}$ & $\begin{array}{r}20,000- \\
30,000 \\
\end{array}$ & $\begin{array}{r}30,000- \\
40,000 \\
\end{array}$ & $\begin{array}{r}40,000- \\
50,000 \\
\end{array}$ & $\begin{array}{r}50,000- \\
75,000 \\
\end{array}$ & $75,000+$ \\
\hline \multicolumn{8}{|c|}{$\begin{array}{l}\text { Households with IRAs or } \\
\text { KEOGHs }\end{array}$} \\
\hline & \multirow[t]{3}{*}{ Net Financial Assets } & 5,233 & 1,807 & 1,412 & 5,826 & 1,348 & 4,618 \\
\hline & & $(0.77)$ & $(0.40)$ & $(0.36)$ & $(1.50)$ & $(0.43)$ & $(1.16)$ \\
\hline & & {$[0.58]$} & {$[0.43]$} & {$[0.32]$} & {$[1.27]$} & {$[0.30]$} & {$[0.41]$} \\
\hline & \multirow[t]{3}{*}{ Wealth } & $-13,411$ & $-4,451$ & 11,266 & 2,067 & $-7,793$ & -665 \\
\hline & & $(0.84)$ & $(0.42)$ & $(1.25)$ & $(0.23)$ & $(1.07)$ & $(0.07)$ \\
\hline & & {$[0.86]$} & {$[0.45]$} & {$[1.25]$} & {$[0.23]$} & {$[0.84]$} & {$[0.04]$} \\
\hline \multicolumn{8}{|c|}{$\begin{array}{l}\text { Households without IRAs or } \\
\text { KEOGHs }\end{array}$} \\
\hline & \multirow[t]{3}{*}{ Net Financial Assets } & 740 & 24 & 2,198 & 52 & 2,911 & 4,664 \\
\hline & & $(4.00)$ & $(0.16)$ & (13.83) & $(0.28)$ & $(16.22)$ & (13.33) \\
\hline & & {$[1.72]$} & {$[0.04]$} & [3.22] & {$[0.05]$} & {$[1.67]$} & [1.03] \\
\hline & \multirow[t]{3}{*}{ Wealth } & 792 & 531 & 8,736 & 3,360 & 6,800 & $-21,476$ \\
\hline & & $(0.54)$ & $(0.44)$ & $(6.87)$ & $(2.23)$ & $(4.73)$ & $(7.66)$ \\
\hline & & {$[0.52]$} & {$[0.33]$} & [2.90] & {$[0.62]$} & {$[1.27]$} & {$[1.01]$} \\
\hline \multicolumn{8}{|c|}{ Homeowners } \\
\hline & \multirow[t]{3}{*}{ Net Financial Assets } & 1,789 & 1,531 & 1,667 & 3,293 & 5,843 & 180 \\
\hline & & $(1.54)$ & $(1.82)$ & $(2.14)$ & (3.98) & $(8.16)$ & $(0.17)$ \\
\hline & & {$[0.91]$} & {$[1.06]$} & [1.13] & {$[1.56]$} & {$[2.46]$} & {$[0.02]$} \\
\hline & \multirow[t]{3}{*}{ Wealth } & 3,778 & 2,440 & -432 & $-4,338$ & -436 & $-24,160$ \\
\hline & & $(0.56)$ & $(0.50)$ & $(0.09)$ & $(0.90)$ & $(0.10)$ & (3.81) \\
\hline & & {$[0.43]$} & {$[0.44]$} & {$[0.06]$} & {$[0.65]$} & {$[0.07]$} & [1.48] \\
\hline \multicolumn{8}{|l|}{ Renters } \\
\hline & \multirow[t]{3}{*}{ Net Financial Assets } & 826 & 599 & 1,408 & $-3,677$ & 243 & 11,728 \\
\hline & & $(5.87)$ & $(4.85)$ & $(9.97)$ & (19.24) & $(1.23)$ & (32.51) \\
\hline & & {$[1.58]$} & {$[0.91]$} & {$[1.20]$} & {$[1.46]$} & {$[0.07]$} & [0.81] \\
\hline
\end{tabular}

* The table reports the results of estimating equation (6). The values in parentheses represent the absolute value of t-statistics using analytical standard errors; the values in square brackets represent the absolute value of t-statistics using bootstrapped standard errors with 200

iterations. Family earnings categories are given in 1991 dollars.

Source: Authors' calculations from the SIPP. 


\section{Table 9}

Effects of 401(k) Eligibility on Ln(Wealth/Earnings), by Saver Group and Earnings Category, 1987-91*

\begin{tabular}{|c|c|c|c|c|c|}
\hline \multirow[b]{2}{*}{ Sample } & \multirow[b]{2}{*}{ Dependent Variable } & \multicolumn{4}{|c|}{ Coefficient on ELIG*IN91*Earnings Category } \\
\hline & & $\begin{array}{r}30,000- \\
40,000 \\
\end{array}$ & $\begin{array}{r}40,000- \\
50,000\end{array}$ & $\begin{array}{r}50,000- \\
75,000 \\
\end{array}$ & $75,000+$ \\
\hline \multicolumn{6}{|l|}{ All } \\
\hline & $\operatorname{In}\left(50,000^{*}\right.$ Net Financial & & & & \\
\hline & Assets/Earnings) & $\begin{array}{l}0.918 \\
(4.00)\end{array}$ & $\begin{array}{l}0.149 \\
(0.58)\end{array}$ & $\begin{array}{l}0.330 \\
(1.43)\end{array}$ & $\begin{array}{r}-0.041 \\
(0.12)\end{array}$ \\
\hline & & [2.61] & [0.54] & [1.52] & {$[0.17]$} \\
\hline & $\ln \left(50,000^{*}\right.$ Wealth/Earnings $)$ & 0.240 & 0.010 & 0.114 & -0.150 \\
\hline & & (2.43) & $(0.09)$ & (1.15) & $(0.98)$ \\
\hline & & [1.48] & {$[0.07]$} & [1.02] & [1.40] \\
\hline \multicolumn{6}{|c|}{$\begin{array}{l}\text { Households with IRAs or } \\
\text { KEOGHs }\end{array}$} \\
\hline & $\ln (50,000 *$ Net Financial & & & & \\
\hline & Assets/Earnings) & 0.208 & 0.131 & 0.029 & -0.024 \\
\hline & & $(1.10)$ & $(0.69)$ & $(0.19)$ & $(0.13)$ \\
\hline & & [0.99] & [0.67] & {$[0.17]$} & [0.11] \\
\hline & $\ln (50,000 *$ Wealth/Earnings $)$ & 0.006 & 0.111 & -0.137 & 0.039 \\
\hline & & $(0.06)$ & $(1.00)$ & $(1.53)$ & $(0.35)$ \\
\hline & & {$[0.04]$} & [0.89] & [1.27] & [0.28] \\
\hline \multicolumn{6}{|c|}{ Homeowners } \\
\hline & $\ln \left(50,000^{*}\right.$ Net Financial & & & & \\
\hline & Assets/Earnings) & 0.448 & 0.184 & 0.376 & -0.066 \\
\hline & & (1.92) & $(0.75)$ & (1.76) & $(0.20)$ \\
\hline & & [1.59] & [0.70] & [1.81] & [0.25] \\
\hline & In(Wealth/Earnings) & 0.037 & -0.032 & 0.052 & -0.205 \\
\hline & & $(0.38)$ & $(0.32)$ & $(0.59)$ & (1.53) \\
\hline & & [0.38] & [0.31] & [0.59] & [1.71] \\
\hline
\end{tabular}

* The table reports the results of estimating equation (6). The values in parentheses represent the absolute value of $t$-statistics using analytical standard errors; the values in square brackets represent the absolute value of $t$-statistics using bootstrapped standard errors with 200 iterations. Family earnings categories are given in 1991 dollars.

Source: Authors' calculations from the SIPP. 
Table 10

Active 401(k) Participation Rates by Earnings and Employer Matching Status, 1988 and 1993*

\begin{tabular}{|c|c|c|c|c|c|c|c|c|}
\hline \multirow[b]{3}{*}{ Individual Earnings } & \multicolumn{2}{|c|}{$\underline{\text { All Eligible Workers }}$} & \multicolumn{6}{|c|}{ Employer Match } \\
\hline & \multirow[b]{2}{*}{1988} & \multirow[b]{2}{*}{1993} & \multicolumn{2}{|c|}{ Yes } & \multicolumn{2}{|c|}{ No } & \multicolumn{2}{|c|}{ Don't Know } \\
\hline & & & 1988 & 1993 & 1988 & 1993 & 1988 & 1993 \\
\hline $0-10,000$ & 30.9 & 37.9 & 39.2 & 50.5 & 31.6 & 50.0 & 11.8 & 24.9 \\
\hline $10,001-20,000$ & 51.2 & 56.5 & 59.0 & 69.8 & 45.7 & 68.0 & 26.5 & 34.2 \\
\hline $20,001-30,000$ & 58.6 & 66.3 & 61.9 & 80.3 & 61.2 & 65.0 & 29.7 & 41.6 \\
\hline $30,001-40,000$ & 62.2 & 73.9 & 64.2 & 84.3 & 67.3 & 78.2 & 31.2 & 46.4 \\
\hline $40,001-50,000$ & 68.1 & 80.6 & 71.9 & 86.7 & 65.0 & 81.7 & 37.2 & 62.8 \\
\hline $50,001-75,000$ & 71.5 & 83.0 & 76.9 & 90.3 & 63.6 & 80.2 & 47.8 & 61.3 \\
\hline 75,001 and up & 83.2 & 88.5 & 84.3 & 95.4 & 84.6 & 86.6 & 55.6 & 66.0 \\
\hline All & 60.3 & 68.2 & 65.0 & 80.6 & 60.3 & 73.3 & 29.2 & 42.1 \\
\hline
\end{tabular}

* Earnings are in 1991 dollars. A worker is defined as actively participating in a $401(\mathrm{k})$ if he or she makes a contribution during the year in question. Source: Authors' calculation from the Current Population Survey. 
Table 11

Average Employee Contribution Among Active Participants, by Year, Earnings, and Employer Matching Status*

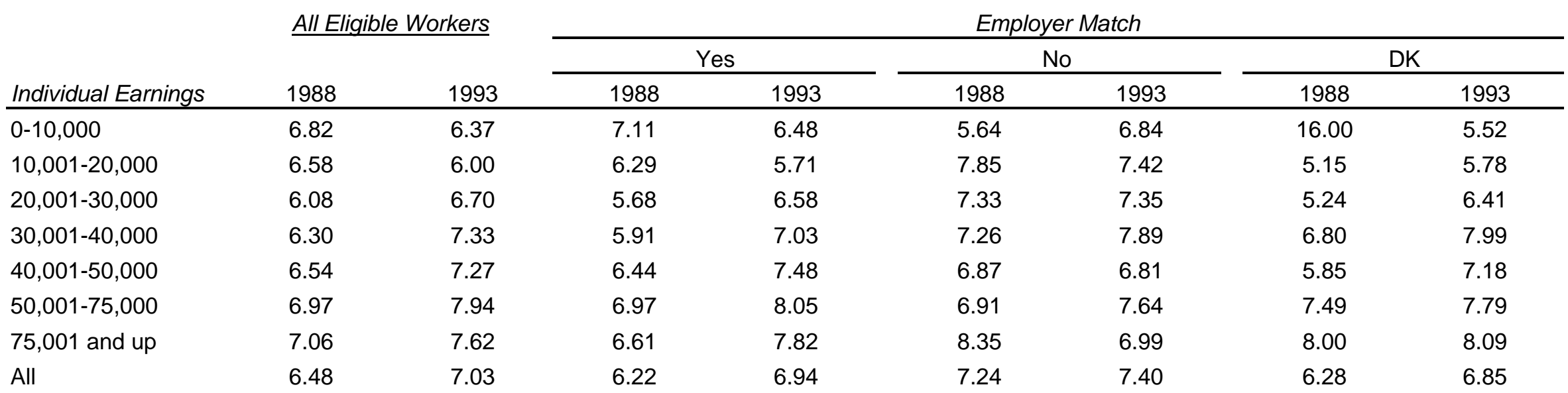

* Earnings are in 1991 dollars. A worker is defined as actively participating in a $401(\mathrm{k})$ if he or she makes a contribution during the year in question. Table entries represent percent of salary.

Source: Authors' calculation from the Current Population Survey. 


\section{Appendix Table 1}

\section{LAD Coefficients, Dependent Variable=Net Financial Assets, Sample=1987 and 1991 Data}

\begin{tabular}{|c|c|c|c|c|c|c|}
\hline \multirow[b]{2}{*}{ Variable } & \multirow[b]{2}{*}{ Coefficient on } & \multicolumn{2}{|c|}{ t-statistic, using } & \multirow[b]{2}{*}{ Coefficient on } & \multicolumn{2}{|c|}{ t-statistic, using } \\
\hline & & $\underline{\mathrm{ASE}^{1}}$ & $\underline{\mathrm{BSE}^{2}}$ & & $\underline{\mathrm{ASE}^{1}}$ & $\underline{B S E}^{2}$ \\
\hline Age $=35-44$ & 530 & 4.33 & 6.19 & 3,277 & 14.92 & 6.51 \\
\hline Age $=45-54$ & 1,564 & 11.21 & 7.68 & 9,135 & 37.13 & 8.54 \\
\hline Age $=55-64$ & 8,194 & 50.62 & 8.71 & 19,756 & 66.53 & 7.47 \\
\hline$E d u=12$ & 392 & 2.65 & 3.92 & 1,568 & 4.95 & 1.72 \\
\hline$E d u=13-15$ & 465 & 2.77 & 3.82 & 2,058 & 6.07 & 1.98 \\
\hline$E d u=16$ & 2,196 & 11.13 & 6.64 & 3,347 & 8.98 & 2.98 \\
\hline Edu>16 & 2,351 & 11.71 & 5.29 & 6,177 & 16.26 & 4.17 \\
\hline Married & 595 & 3.56 & 4.15 & 2,989 & 9.49 & 3.13 \\
\hline White & 522 & 3.59 & 4.42 & 3,044 & 11.50 & 4.85 \\
\hline Male & 187 & 1.42 & 1.77 & 942 & 3.99 & 1.75 \\
\hline Two-Earners & $-1,379$ & -10.44 & -7.48 & $-4,552$ & -18.91 & -4.72 \\
\hline Family Size & -226 & -5.60 & -5.92 & -734 & -9.96 & -3.51 \\
\hline Have DB & 101 & 0.98 & 0.99 & -411 & -2.24 & -0.82 \\
\hline$y=10-20$ & -- & -- & & -- & -- & \\
\hline$y=20-30$ & 374 & 2.01 & 3.33 & 823 & 1.56 & 0.92 \\
\hline$y=30-40$ & 1,165 & 5.67 & 5.20 & 2,974 & 5.69 & 2.72 \\
\hline$y=40-50$ & 2,575 & 10.92 & 6.78 & 5,460 & 9.94 & 4.65 \\
\hline$y=50-75$ & 5,915 & 24.64 & 8.89 & 9,696 & 18.12 & 5.75 \\
\hline$y=75+$ & 19,429 & 55.92 & 8.92 & 18,264 & 28.25 & 4.21 \\
\hline In91*y10-20 & 125 & 0.67 & 1.28 & 512 & 1.00 & 0.70 \\
\hline In91*y20-30 & -120 & -0.62 & -0.88 & 333 & 0.82 & 0.41 \\
\hline $\ln 91^{*} y 30-40$ & -145 & -0.62 & -0.51 & 998 & 2.47 & 0.97 \\
\hline $\ln 91^{*} y 40-50$ & 133 & 0.46 & 0.24 & 1,965 & 4.32 & 1.27 \\
\hline $\ln 91^{*} y 50-75$ & $-1,155$ & -4.02 & -0.88 & 4,079 & 10.05 & 1.71 \\
\hline $\ln 91^{*} \mathrm{y} 75+$ & 7,723 & 16.80 & 1.57 & 572 & 0.91 & 0.18 \\
\hline Constant & -976 & -3.89 & -4.33 & $-4,847$ & -8.24 & -3.55 \\
\hline
\end{tabular}

\footnotetext{
${ }^{1}$ Analytical Standard Errors.

${ }^{2}$ Bootstrapped Standard Errors.
} 


\section{Appendix Table 2}

\section{LAD Coefficients, Dependent Variable=Wealth,}

Sample=1987 and 1991 Data

\begin{tabular}{|c|c|c|c|c|c|c|}
\hline \multirow[b]{2}{*}{ Variable } & \multicolumn{3}{|c|}{ t-statistic, using } & \multicolumn{3}{|c|}{ t-statistic, using } \\
\hline & $\begin{array}{l}\text { Coefficient } \\
\text { on Variable }\end{array}$ & $\underline{\mathrm{ASE}^{1}}$ & $\mathrm{BSE}^{2}$ & $\begin{array}{r}\text { Coefficient on } \\
\text { Variable*Eligibility }\end{array}$ & $\underline{\mathrm{ASE}^{1}}$ & $\underline{B S E}^{2}$ \\
\hline Age $=35-44$ & 6,475 & 11.74 & 5.02 & 9,251 & 9.34 & 4.16 \\
\hline Age $=45-54$ & 25,613 & 40.67 & 8.58 & 19,652 & 17.71 & 5.22 \\
\hline Age $=55-64$ & 60,522 & 82.91 & 31.65 & 26,821 & 20.03 & 5.96 \\
\hline$E d u=12$ & 4,739 & 7.10 & 6.23 & 365 & 0.26 & 0.17 \\
\hline$E d u=13-15$ & 4,729 & 6.24 & 3.99 & 1,078 & 0.71 & 0.45 \\
\hline$E d u=16$ & 7,217 & 8.11 & 4.32 & 2,531 & 1.51 & 0.85 \\
\hline Edu $>16$ & 6,675 & 7.36 & 4.50 & 6,714 & 3.92 & 1.95 \\
\hline Married & 4,010 & 5.32 & 5.24 & 8,128 & 5.72 & 2.71 \\
\hline White & 4,744 & 7.24 & 8.39 & 5,841 & 4.89 & 3.17 \\
\hline Male & 1,781 & 3.01 & 1.71 & 1,291 & 1.21 & 0.79 \\
\hline Two-Earners & $-5,411$ & -9.08 & -3.58 & $-9,946$ & -9.16 & -3.23 \\
\hline Family Size & 755 & 4.15 & 2.16 & 232 & 0.70 & 0.35 \\
\hline Have DB & 1,240 & 2.64 & 1.70 & -472 & -0.57 & -0.33 \\
\hline$y=10-20$ & -- & -- & & -- & -- & \\
\hline$y=20-30$ & 2,804 & 3.34 & 2.00 & 2,960 & 1.25 & 1.05 \\
\hline$y=30-40$ & 13,217 & 14.26 & 5.30 & -424 & -0.18 & -0.11 \\
\hline$y=40-50$ & 21,605 & 20.29 & 6.03 & 6,402 & 2.58 & 1.24 \\
\hline$y=50-75$ & 32,566 & 30.10 & 16.11 & 14,510 & 6.01 & 2.94 \\
\hline$y=75+$ & 91,891 & 58.65 & 12.09 & 17,574 & 6.03 & 1.49 \\
\hline $\ln 91^{*} y 10-20$ & -462 & -0.55 & -0.34 & 1,706 & 0.74 & 0.64 \\
\hline In91*y20-30 & $-2,461$ & -2.84 & -3.59 & 301 & 0.17 & 0.15 \\
\hline $\ln 91^{*} y 30-40$ & $-7,304$ & -6.90 & -2.06 & 3,976 & 2.18 & 0.92 \\
\hline $\ln 91^{*} y 40-50$ & $-1,916$ & -1.48 & -0.61 & $-1,574$ & -0.77 & -0.32 \\
\hline $\ln 91^{*} y 50-75$ & $-3,259$ & -2.52 & -0.89 & 344 & 0.19 & 0.06 \\
\hline $\ln 91^{*} y 75+$ & $-2,152$ & -1.04 & -0.20 & $-5,520$ & -1.95 & -0.35 \\
\hline Constant & $-12,262$ & -10.83 & -9.82 & $-10,159$ & -3.83 & -3.06 \\
\hline
\end{tabular}

\footnotetext{
${ }^{1}$ Analytical Standard Errors.

${ }^{2}$ Bootstrapped Standard Errors.
} 


\section{Appendix Table 3}

Effects of 401(k) Eligibility on Household Wealth Levels, by Earnings Category, 1987-91: Robust Regression*

Coefficient on ELIG*IN91*Earnings Category

\begin{tabular}{lrrrrrr} 
& \multicolumn{7}{c}{\begin{tabular}{c}
$c$ \\
\cline { 2 - 6 } Dependent Variable
\end{tabular}} & $\begin{array}{r}10,000- \\
20,000\end{array}$ & 30,000 & $40,000-$ & $40,000-$ & $50,000-$ & \\
\cline { 2 - 7 } Net Financial Assets & & & & & & \\
& 1,466 & 135 & 2,052 & -143 & 1,966 & $-1,709$ \\
& $(1.74)$ & $(0.20)$ & $(3.09)$ & $(0.19)$ & $(2.95)$ & $(1.66)$
\end{tabular}

Net Financial Assets -

Saving Incentive Balances

\begin{tabular}{|c|c|c|c|c|c|}
\hline $\begin{array}{r}197 \\
(0.35)\end{array}$ & $\begin{array}{r}-409 \\
(0.93)\end{array}$ & $\begin{array}{r}543 \\
(1.23)\end{array}$ & $\begin{array}{r}-595 \\
(1.20)\end{array}$ & $\begin{array}{r}-136 \\
(0.31)\end{array}$ & $\begin{array}{r}-2,435 \\
(3.56)\end{array}$ \\
\hline $\begin{array}{l}3,225 \\
(092)\end{array}$ & 247 & 2,940 & $-1,371$ & 590 & $\begin{array}{r}-11,868 \\
(276)\end{array}$ \\
\hline
\end{tabular}

Wealth - Saving Incentive

Balances

$\begin{array}{rrrrrr}294 & -1,731 & 330 & -4,426 & -2,583 & -21,330 \\ (0.09) & (0.67) & (0.13) & (1.56) & (1.02) & (5.46)\end{array}$

* The table reports the results of estimating equation (6). The values in parentheses represent the absolute value of t-statistics. Family earnings categories are given in 1991 dollars.

Source: Authors' calculations from the SIPP. 


\section{Appendix Table 4}

\section{Effects of 401(k) Eligibility on Wealth/Earnings Ratios, by Saver Group and Earnings Category, 1987-91*}

Coefficient on ELIG*IN91 *Earnings Category

Sample

All

Households with IRAs or

KEOGHs

Households without IRAs or KEOGHs

Homeowners

Renters

Dependent Variable

Net Financial

Assets/Earnings

0.035

(2.02)

[1.11]

0.017

(1.27)

[0.68]

0.094

$-0.012$

(1.12)

(0.18)

[0.90]

[0.14]

Net Financial
Assets/Earnings

Wealth/Earnings

Net Financial

Assets/Earnings

Wealth/Earnings

Net Financial

Assets/Earnings

Wealth/Earnings

(3.91)

[1.29]

0.063
$(1.78)$

[0.89]

0.037
$(5.20)$

0.007

(1.24)

[0.36]

0.152

0.023

(0.46)

[2.13]

[0.31]

(0.34)

[0.28]

$-0.522$

(2.29)

[1.13]

0.100

(0.90)

[0.79]

0.034

(2.49)

[1.21]

0.062

(0.93)

[0.62]

40,000

50,000

50,000

75,000

\subsection{8}

(1.85)

[0.78]

0.057

(4.20)

[1.65]

$-0.016$

(0.21)

[0.14]

0.124

(1.88)

[1.59]

0.090

(0.46)

[0.34]

0.092

(0.82)

[0.94]

$-0.010$

(0.11)

[0.14]

0.076

(0.39)

[0.38]

$-0.092$

(0.59)

[0.56]

0.046

(7.44)

[2.28]

0.200

(3.86)

[2.38]

$-0.007$

(0.91)

[0.27]

0.046

(6.59)

[1.51]

0.008

0.189

(3.22)

[2.14]

[0.08]

0.046

(1.93)

(0.40)

[0.23]

[1.38]

0.061

(2.40)

[1.36]

0.080

(3.63)

[1.98]

$-0.063$

0.137

(1.22)

(0.58)

[0.46]

-0.009
$(0.08)$

(0.48)

[0.50]

[1.60]

[0.09]

0.023

(3.79)

[0.87]
0.034

(5.06)

[0.97]
$-0.066$

(7.16)

[1.23]
$-0.012$

(1.23)

[0.19]
[0.67]
0.026

(0.23)

[0.24]

$-0.069$

(0.34)

[0.33]

\footnotetext{
* The table reports the results of estimating equation (6). The values in parentheses represent the absolute value of t-statistics using analytical standard errors; the values in square brackets represent the absolute value of t-statistics using bootstrapped standard errors with 200 iterations. Family earnings categories are given in 1991 dollars.
}

Source: Authors' calculations from the SIPP. 
Appendix Table 5

Effects of 401(k) Eligibility on Ln(Wealth), by Saver Group and Earnings Category, 1987-91*

\begin{tabular}{|c|c|c|c|c|c|}
\hline \multirow[b]{2}{*}{ Sample } & \multirow[b]{2}{*}{ Dependent Variable } & \multicolumn{4}{|c|}{ Coefficient on ELIG*IN91*Earnings Category } \\
\hline & & $\begin{array}{r}30,000- \\
40,000 \\
\end{array}$ & $\begin{array}{r}40,000- \\
50,000 \\
\end{array}$ & $\begin{array}{r}50,000- \\
75,000 \\
\end{array}$ & $75,000+$ \\
\hline \multicolumn{6}{|l|}{ All } \\
\hline & $\ln ($ Net Financial Assets) & 1.033 & 0.128 & 0.438 & 0.023 \\
\hline & & $(4.63)$ & $(0.51)$ & (1.96) & $(0.07)$ \\
\hline & & [3.00] & {$[0.45]$} & {$[1.76]$} & {$[0.09]$} \\
\hline & In(Wealth) & 0.272 & 0.023 & 0.173 & -0.129 \\
\hline & & $(2.81)$ & $(0.21)$ & (1.79) & $(0.86)$ \\
\hline & & [1.70] & {$[0.17]$} & [1.75] & [1.01] \\
\hline \multicolumn{6}{|c|}{ Households with IRAKEOs } \\
\hline & In(Net Financial Assets) & 0.130 & 0.158 & -0.051 & -0.080 \\
\hline & & $(0.56)$ & $(0.68)$ & $(0.27)$ & $(0.34)$ \\
\hline & & [0.55] & {$[0.80]$} & [0.32] & [0.41] \\
\hline & $\ln$ (Wealth) & -0.052 & 0.061 & -0.091 & 0.058 \\
\hline & & $(0.41)$ & $(0.49)$ & $(0.91)$ & $(0.45)$ \\
\hline & & {$[0.30]$} & [0.44] & {$[0.76]$} & [0.42] \\
\hline \multicolumn{6}{|c|}{ Homeowners } \\
\hline & In(Net Financial Assets) & 0.470 & 0.184 & 0.258 & 0.206 \\
\hline & & (2.05) & $(0.76)$ & $(1.48)$ & $(0.35)$ \\
\hline & & [1.50] & {$[0.71]$} & [1.51] & [0.41] \\
\hline & $\ln$ (Wealth) & 0.005 & -0.033 & 0.096 & -0.150 \\
\hline & & $(0.05)$ & $(0.33)$ & $(1.14)$ & (1.18) \\
\hline & & [0.04] & [0.31] & [1.08] & [1.18] \\
\hline
\end{tabular}

* The table reports the results of estimating equation (6). Only households with income over $\$ 30,000$ are included in the sample. The values in parentheses represent the absolute value of t-statistics using analytical standard errors; the values in square brackets represent the absolute value of t-statistics using bootstrapped standard errors with 200 iterations. Family earnings categories are given in 1991 dollars.

Source: Authors' calculations from the SIPP. 